\title{
The NAD Metabolome is Functionally Depressed in Patients Undergoing Liver Transplantation for Alcohol-related Liver Disease
}

Richard Parker ${ }^{1,2}$, Mark S. Schmidt ${ }^{3}$, Owen Cain ${ }^{3}$, Bridget Gunson ${ }^{1}$, Charles Brenner ${ }^{4}$

1. Centre for Liver Research, University of Birmingham, Vincent Drive, Birmingham B15 2TT United Kingdom

2. Liver and Hepatobiliary Unit, University Hospitals Birmingham NHS Foundation Trust, Mindelsohn Drive, Birmingham B15 2TH United Kingdom

3. Histopathology, University Hospitals Birmingham NHS Foundation Trust, Birmingham B15 2TH United Kingdom

4. Department of Biochemistry, Carver College of Medicine, University of lowa, USA

Author contact information:

Richard Parker: richardparker@nhs.net

Mark S. Schmidt: mark-schmidt@uiowa.edu

Owen Cain: owen.cain@uhb.nhs.uk

Bridget Gunson: b.k.gunson@bham.ac.uk

Charles Brenner: charles-brenner@uiowa.edu

Keywords: quantitative targeted metabolomics, cirrhosis, steatohepatitis, myeloperoxidase, clinical research

\section{Grants and Financial Support:}

Supported by funds from the Roy J. Carver Charitable Trust to CB. 


\section{Corresponding Authors:}

Richard Parker

Leeds Liver Unit, St James's University Hospital

\section{Beckett Street}

Leeds, West Yorkshire LS9 7TF

United Kingdom

E-mail: richardparker@nhs.net

Tel.: +44-(0)-113-2066704

\section{Charles Brenner}

Carver College of Medicine, University of lowa

51 Newton Road, 4-403 Bowen Science Building (BSB)

lowa City, lowa 52242

United States

E-mail: charles-brenner@uiowa.edu

Tel.: +1-319-335-7934

\section{Abbreviations:}

ArLD, alcohol-related liver disease; $\mathrm{AH}$, alcoholic hepatitis; $\mathrm{ASH}$, alcoholic steatohepatitis; $\mathrm{NAD}^{+}$, nicotinamide adenine dinucleotide; LC-MS, liquid chromatography-mass spectrometry; $\mathrm{NADH}$, reduced form of $\mathrm{NAD}$; $\mathrm{NADP}^{+}$, nicotinamide adenine dinucleotide phosphate; AMPK, AMP-activated protein kinase; SIRTI, sirtuin-1; DNA, deoxyribose nucleic acid; NAM, nicotinamide; NA, nicotinic acid; NR, nicotinamide riboside; UBH, University Hospitals Birmingham NHS Foundation Trust; NAFLD, non-alcoholic fatty liver disease; PSC, primary sclerosing cholangitis; PBC, primary biliary cholangitis; BMI, body mass index; ANOVA, 
bioRxiv preprint doi: https://doi.org/10.1101/2020.03.28.013581; this version posted March 30, 2020. The copyright holder for this preprint (which was not certified by peer review) is the author/funder, who has granted bioRxiv a license to display the preprint in perpetuity. It is made available under aCC-BY-ND 4.0 International license.

analysis of variance; AST, aspartate transaminase; cADPR, cyclic ADP ribose; NASH, nonalcoholic steatohepatitis; 


\section{Abstract}

Nicotinamide adenine dinucleotide $\left(\mathrm{NAD}^{+}\right)$and related coenzymes play critical roles in liver function. Though hepatic alcohol metabolism depresses $\mathrm{NAD}^{+}$, current understanding of the $\mathrm{NAD}^{+}$metabolome in alcohol-related liver disease (ArLD) is based on animal models. We used human liver samples to quantify the $\mathrm{NAD}^{+}$metabolome in ArLD with samples obtained at the time of liver transplantation or resection at University Hospitals Birmingham NHS Foundation Trust (UHB). The severity of steatohepatitis in liver from patients with ArLD was assessed with standard liver function tests (LFT) and histology. NAD-targeted quantitative metabolomic analysis of liver tissue was performed by liquid chromatography-tandem mass spectrometry (LC-MS). Seventy-two human liver specimens were analyzed including 43 with ArLD. The $\mathrm{NAD}^{+}$metabolome differed significantly between different types of liver disease (two-way ANOVA $p=0.001)$. ArLD liver tissue showed markedly depressed concentrations of $\mathrm{NAD}^{+}(432$ $\mu \mathrm{M}$ vs. $616 \mu \mathrm{M}$ in $\mathrm{NL}$ ) and precursor molecules nicotinic acid and nicotinamide riboside. There was a significant overall difference in the $\mathrm{NAD}^{+}$metabolome between ArLD samples with and without steatohepatitis (two-way ANOVA $p=0.018$ ). After correcting for multiple comparisons, a significant difference for individual components of the metabolome was observed for the concentration of $\mathrm{NAD}^{+}$(mean $451 \mu \mathrm{M}$ vs. $381 \mu \mathrm{M}, \mathrm{p}=0.045$ ). $\mathrm{NAD}^{+}$concentration was inversely related to serum bilirubin concentration $\left(r^{2}-0.127, p=0.04\right)$ and positively correlated with myeloperoxidase activity $\left(r^{2} 0.31, \mathrm{p}=0.003\right)$. The concentration of $\mathrm{NAD}^{+}$and its precursor molecules are significantly reduced in ArLD and are associated with disease activity. Conclusion: Liver samples from people with ArLD show depressed $\mathrm{NAD}^{+}$and precursor levels as well as depressed myeloperoxidase activity. 


\section{Introductory Statement}

Alcohol related liver disease (ArLD) is common throughout the world, causing a significant burden of morbidity and premature mortality (1-3). ArLD follows a course from simple hepatic steatosis through steatohepatitis to cirrhosis and hepatocellular carcinoma. The exception to this is acute alcoholic hepatitis $(\mathrm{AH})$, which can occur at any stage along this spectrum. $\mathrm{AH}$ is characterized clinically by jaundice and liver failure(4) with steatohepatitis (alcoholic steatohepatitis, $\mathrm{ASH}$ ) and cholestasis seen histologically(5). AH is associated with poor shortterm mortality, which has not improved over time despite multiple tested interventions(6). Hepatic metabolism is markedly impaired in $\mathrm{AH}$. For example, urea disposal(7) and hepatic mitochondrial function(8) are significantly depressed.

Nicotinamide adenine dinucleotide $\left(\mathrm{NAD}^{+}\right)$is the central regulator of metabolism as coenzyme for hydride transfer reactions and as a substrate of $\mathrm{NAD}^{+}$-consuming enzymes including sirtuins, which are responsible for $\mathrm{NAD}^{+}$-dependent protein lysine deacylation(9). $\mathrm{NAD}^{+}$is a hydride group acceptor in the oxidation of carbohydrates, amino acids and fats, forming NADH. $\mathrm{NADH}$ is reoxidized to $\mathrm{NAD}^{+}$by the electron transfer chain in oxidative phosphorylation. In addition, $\mathrm{NADH}$ is also reoxidized to $\mathrm{NAD}^{+}$in hepatic gluconeogenesis and ketogenesis. Obesity and type 2 diabetes moderately depress hepatic $\mathrm{NAD}^{+}$, while greatly depressing hepatic $\mathrm{NADP}^{+}$and $\mathrm{NADPH}(10)$. Alcohol metabolism depresses hepatic $\mathrm{NAD}^{+}$ concentration(11) on the basis of two successive oxidation reactions in which $\mathrm{NAD}^{+}$is reduced to $\operatorname{NADH}(12,13)$. This is accompanied by increased liver protein acetylation(14, 15), reduced hepatic AMPK activity(16), and reduced SIRT1 expression and activity(17, 18). Depressed $\mathrm{NAD}^{+}$synthesis in liver is associated with accumulated DNA damage and carcinogenesis(19). In addition sirtuins, particularly (SIRT1), are protective against alcohol and obesity-induced hepatic injury(20-22) and require $\mathrm{NAD}^{+}$as a cofactor. 
Depression of the $\mathrm{NAD}^{+}$metabolome can be counteracted by de novo $\mathrm{NAD}^{+}$synthesis from tryptophan or via salvage pathways from precursor vitamins, nicotinamide (NAM), nicotinic acid (NA) and nicotinamide riboside (NR)(23, 24). In rodent models, hepatic carcinogenesis(19), diet-induced steatosis(25), alcohol-induced liver injury(26) and fibrosis (27) can be counteracted by provision of NR, while NA protects against alcoholic fatty liver(11). Moreover, in mice, the condition of postpartum depresses the maternal hepatic NAD metabolome (28) and endogenous metabolism of NR is protective against diet-induced liver damage(29). However, the present understanding of the normal and diseased hepatic $\mathrm{NAD}^{+}$metabolome is based solely on animal models of ArLD. Here we used human liver samples to assess the NAD metabolome in liver diseases and discovered functionally important and actionable associations with clinical markers of disease. 


\section{Experimental Procedures}

\section{Human samples}

Human liver specimens were obtained at the time of transplantation or resection of metastatic disease from University Hospitals Birmingham NHS Foundation Trust (UHB). Collection and use of tissue for research was approved by the research ethics committee (Birmingham research ethics committee, reference 06/Q2708/11). All patients gave signed, informed consent for the use of their tissue and data. All procedures involved in the research were performed in concordance with relevant guidelines and legal regulations. Tissues were snap-frozen in liquid nitrogen and stored at $-80{ }^{\circ} \mathrm{C}$ until use. Specimens were obtained from patients without hepatocellular carcinoma or cholangiocarcinoma who underwent liver transplantation for decompensated cirrhosis due to ArLD, non-alcoholic fatty liver disease (NAFLD), primary sclerosing cholangitis (PSC) or primary biliary cholangitis (PBC). In addition, liver tissue was obtained from patients undergoing liver resection, usually for metastatic disease, who had otherwise normal background liver tissue and who had not received adjuvant chemotherapy within 6 weeks of liver resection. Samples were taken from sites distal to the lesion that was resected.

Patients undergoing liver transplantation for ArLD were assessed for abstinence by addiction specialists and monitored with blood and breath testing for evidence of alcohol use during their time on the transplant wait list. During the period of this research project there was an expectation of six months of abstinence before listing for liver transplantation. For control samples, clinical records were reviewed to exclude patients who consumed more than UK government recommended amounts of alcohol (14 units $/ 126 \mathrm{~g}$ of alcohol per week). Infection with hepatitis viruses was routinely excluded in all patients by testing for viral serology.

\section{Clinical information}

Routine clinical data were noted: age, sex, body mass index (BMI) and laboratory parameters. The presence and severity of ASH in liver tissue specimens from patients with ArLD was based 
on a scoring system proposed by Altamirano and colleagues (30). Fibrosis was excluded given that all specimens were fibrotic. Included in histological assessment were steatosis (scored from $0-2)$, ballooning of hepatocytes (0-1), neutrophilic infiltration (0-1), bilirubinostasis (0-3) and megamitochondria $(0-1)$, giving a final overall score up to a maximum of 8 points. ASH was defined as non-severe/severe with a cut off of 3 points or above.

\section{Quantitative targeted analysis of the NAD metabolome}

Sample extraction, liquid chromatography-mass spectrometry and quantification were performed as described(10, 25). As the reduced coenzymes become oxidized and to some degree lost in extraction, the values of $\mathrm{NAD}^{+}$and $\mathrm{NADP}^{+}$are taken as indicators of the sum of hepatic $\mathrm{NAD}^{+}$plus $\mathrm{NADH}$ and $\mathrm{NADP}^{+}$plus NADPH. As a rule, most of the $\mathrm{NAD}^{+}$plus NADH pool would be expected to be in the $\mathrm{NAD}^{+}$form, whereas most of the $\mathrm{NADP}^{+}$plus NADPH pool would be in the NADPH form.

\section{Measurement of oxidative stress in liver tissue}

Oxidative stress in human liver tissue specimens was assessed by measuring glutathione content, malonaldehyde content, myeloperoxidase activity and superoxidase dismutase activity using colorimetric assays (Cell Bio Laboratories, San Diego, USA) according to manufacturer's instructions. This was performed when sufficient quantity of sample remained after metabolomic analysis and hence results are not available for all 43 patients with ArLD.

\section{Statistics}

When considering all diagnostic groups, overall differences in components of the $\mathrm{NAD}^{+}$ metabolome were compared with one-way analysis of variance (ANOVA). When ArLD was compared to the aggregate values all other non-ArLD liver diseases, student's t-tests were used as data were normally distributed. To consider individual components of the NAD metabolome (between normal and ArLD liver tissue, or ArLD specimens with or without steatohepatitis) Sidak's method to correct for multiple comparisons was used. Statistical analyses were performed in Prism v6 for Mac (GraphPad, San Diego, USA). 
bioRxiv preprint doi: https://doi.org/10.1101/2020.03.28.013581; this version posted March 30,2020. The copyright holder for this preprint (which was not certified by peer review) is the author/funder, who has granted bioRxiv a license to display the preprint in perpetuity. It is made available under aCC-BY-ND 4.0 International license. 


\section{Results}

In total, 72 human liver specimens were analyzed: 43 specimens of liver from patients with ArLD, 5 NAFLD, 5 PSC, 5 PBC and 14 specimens of normal liver. Clinical characteristics of each group are shown in Table 1. Groups differed with regard to body mass index (BMI), serum aspartate transaminase (AST) concentration and serum glucose. These values were distributed as would be expected by each diagnosis. The histological characteristics of the samples from ArLD specimens are shown in supplementary table 1.

\section{The NAD metabolome in depressed in ArLD}

LC-MS analysis showed the NAD ${ }^{+}$metabolome differed significantly between different types of liver disease (two-way ANOVA p<0.01) (Fig. 1, Table 2). In particular, specimens from ArLD liver showed markedly depressed $\mathrm{NAD}^{+}(432 \mu \mathrm{M}$ vs. $616 \mu \mathrm{M}$ in $\mathrm{NL}, \mathrm{p}<0.001)$ and $\mathrm{NADP}^{+}(99$ $\mu \mathrm{M}$ vs. $236 \mu \mathrm{M}$ in $\mathrm{NL}, \mathrm{p}<0.001$ ) (Fig. $1 \mathrm{~A}, \mathrm{E}$ ). Levels of $\mathrm{NAD}$ precursors $\mathrm{NA}$ and $\mathrm{NR}$ were markedly lower in all liver diseases including ArLD (1.94 $\mu \mathrm{M}$ vs 5.74 in normal liver tissue, and $4.0 \mu \mathrm{M}$ vs. 19.6 in normal liver tissue respectively (Fig. 1C,G).

\section{Depressed $\mathrm{NAD}^{+}$is associated with clinical and histological findings}

Specimens from ArLD liver were grouped by the histological severity of $\mathrm{ASH}$. Of the 43 specimens analyzed, $9(21 \%)$ had severe ASH. There was a significant overall difference in the $\mathrm{NAD}^{+}$metabolome between groups (two-way ANOVA p=0.03) (Fig. 2, Table 2). After correcting for multiple comparisons, a significant difference for individual components of the metabolome in liver tissue was observed only in $\mathrm{NAD}^{+}$concentration (mean $462 \mu \mathrm{M}$ vs. $322 \mu \mathrm{M}, \mathrm{p}<0.01$ in non-severe versus severe ASH). Comparison of metabolomic data with clinical and laboratory values showed a statistically significant inverse correlation between serum bilirubin concentration and $\mathrm{NAD}^{+}$content of liver tissue $\left(r^{2} 0.127, \mathrm{p}=0.04\right)$ (Fig. 3). Whereas AST, $\mathrm{HbA1c}$ and $\mathrm{BMI}$ all trended in the same direction as bilirubin, there was little indication that ALT or age have a meaningful correlation with hepatic $\mathrm{NAD}^{+}$concentration in the sampled population. 


\section{Association with oxidative stress}

ArLD is driven by oxidative stress caused by the metabolism of alcohol in hepatocytes (31) and is also associated with increased prevalence and severity of bacterial infections (32). To further examine the association of $\mathrm{NAD}^{+}$metabolites with disease activity, human liver samples were analyzed for glutathione levels and superoxidase dismutase activity and content of thiobarbituric acid reactive substances (TBARS) and myeloperoxidase activity. Whereas there was a trend toward lower glutathione levels and higher levels of superoxide dismutase activity consistent with an elevated burden of reactive oxygen species, there was a clear depression of TBARS $(9.88 \mu \mathrm{M}$ vs. $25.7 \mu \mathrm{M}$, student's t-test $\mathrm{p}<0.001)$ and myeloperoxidase activity $(27.2$ $\mathrm{mU} / \mathrm{mL}$ vs. $47.3 \mathrm{mU} / \mathrm{mL}$, students t-test $0<0.001$ ) compared to normal liver tissue (Fig. 4). In addition, myeloperoxidase activity correlated with $\mathrm{NAD}^{+}$content of liver tissue $\left(r^{2} 0.31, p=\right.$ 0.003) (Fig. 5). 


\section{Discussion}

These data constitute the first report of the $\mathrm{NAD}^{+}$metabolome in human liver biopsies. Using samples from explanted and resected liver tissue, we show that the concentration of $\mathrm{NAD}^{+}$and precursor molecules are significantly lower in ArLD compared to other liver diseases and normal liver tissue. The concentration of $\mathrm{NAD}^{+}$is inversely correlated with disease activity, defined by histological presence of steatohepatitis and serum bilirubin and decreased myeloperoxidase activity. The functional consequences of depressed $\mathrm{NAD}^{+}$and $\mathrm{NADPH}$ concentration is to retard fuel oxidation and limit ROS-dependent antibacterial defenses in disease states, exacerbating and perpetuating liver injury. It is noteworthy that these changes persist despite abstinence indicating ongoing liver damage and the possibility for therapeutic intervention.

The liver has the potential not only to produce NAD coenzymes but also to circulate NAD precursors to other tissues $(33,34)$. In this regard, it was interesting that levels of NA were strikingly depressed in liver diseases. It should be noted that there is no known mechanism for vertebrate formation of NA other than bacterial deamidation of NAM, which one would expect to occur largely in the gut(23). This also constitutes the first observation of substantive NR concentration in non-supplemented human tissues. The role of endogenous NR metabolism has been heightened by recent observation that loss of hepatic NRK1 expression depresses liver function and that endogenous hepatic NRK1 expression declines in mice on high fat $\operatorname{diet}(29,35)$.

Whereas levels of NMN, NAM were unremarkable with respect to human disease state, several other metabolites appear to be characteristically dysregulated. Non-alcoholic steatohepatitis (NASH) liver samples had somewhat depressed levels of NAD co-enzymes. Essentially all of the missing $\mathrm{NAD}^{+}$and $\mathrm{NADP}^{+}$was made up for by an increase in ADPR $(P=0.019)$. PSC samples, on the other hand, had half the ADPR levels found in NL. These data would suggest 
that ADPR-forming enzymes such as poly(ADP-ribose) polymerase plus poly(ADP-ribose) glycohydrolase might be overactive in NASH and depressed in PSC. Such NAD-consuming enzymes necessarily liberate NAM with production of ADPR-related metabolites(9). Though NAM, me2PY and me4PY levels were not modulated by disease state, the levels of MeNAM were elevated in all disease conditions, suggesting that NNMT activity may limit NAD salvage in human liver disease(36).

The depression of TBARS and myeloperoxidase activity compared to normal liver tissue could be interpreted as a defect in neutrophil functions required for antibacterial protection in the alcoholic liver (37). Experimental models of liver disea se have often indicated an increase in TBARS during the development of liver injury, but TBARS has been noted to fall as fibrosis advances (38). It is well recognised that steatosis falls away as fibrosis increases so lipid substrates may be less available in cimhosis. Importantly, data from human liver regarding TBARS measurements are lacking. Our observations may therefore reflect TBARS activity in advanced disease. Conversely, myeloperoxidase activity has frequently been desc ribed in the context of human alc oholic liver disea se and our observations are consistent with impaired neutrophil repsonses (39). The association with reduced $\mathrm{NAD}^{+}$availability reinforces the link with defects in immune function.

This study has limitations. The necessary use of explant or resection material excluded patients who were actively drinking or those with clinically severe $\mathrm{AH}$. These groups may be studied as laboratory techniques improve, and as early liver transplantation for severe $\mathrm{AH}$ becomes more widespread allowing greater access to specimens for research purposes. Nevertheless histological assessment of severity allows for careful extrapolation of our results to a wider population of patients with ArLD. For similar reasons, the very limited availability of normal liver tissue meant that we relied on resection specimens. We were careful to exclude those who drank hazardous alcohol or with evidence of liver disease including a prior diagnosis of NAFLD - although we note that this group had on average a high BMI and $\mathrm{HbA1c}$. Moreover, use of 
explanted tissue from transplant patients necessarily restricted data to end-stage disease. This may not accurately reflect earlier stages of ArLD.

The degree of active disease is likely much less than non-transplant patients, as actively drinking patients are excluded from transplantation. Nevertheless, in common with other transplant programs around the globe, examination of explanted liver tissue occasionally demonstrates a degree of steatohepatitis. This is thought to sometimes relate to covert alcohol consumption(40) although steatohepatitis can take some time to resolve even with abstinence(41). The presence of steatohepatitis signifies active hepatic inflammation rather than simple 'burnt-out' cirrhosis. As the key barometer of alcoholic steatohepatitis(42), it was interesting that bilirubin also showed a significant correlation with hepatic $\mathrm{NAD}^{+}$concentration. It is notable that despite the period of abstinence, our data are comparable to observations in experimental models of ArLD where animals are actively consuming alcohol up to the time of analysis. Li et al observed lower hepatic $\mathrm{NAD}^{+}$content in rats given ad libitum alcohol(11), while Wang and colleagues showed that mice given chronic and binge alcohol for 10 days had reduced hepatic $\mathrm{NAD}^{+}$content(26).

Animal models have also shown that methods to increase $\mathrm{NAD}^{+}$content can improve alcohol induced liver disease. In particular, in rodent models, supplementation of either NA(43, 44) or $N R(26)$ can protect against alcoholic liver injury. On the basis of recent data showing that NR has the highest level of hepatic oral availability of the $\mathrm{NAD}^{+}$precursor vitamins(25), that endogenous NR metabolism protects the liver $(29,35)$ and that high dose NR is safe and potentially valuable in and fatty liver(45), measures to increase $\mathrm{NAD}^{+}$content in human liver might be of clinical benefit. Vitamin B1 supplementation is well established in ArLD, primarily for the prophylaxis or treatment of Wernicke's encephalopathy. Our data raise the intriguing possibility that vitamin B3 supplementation may be beneficial for present or former abusers of alcohol, though this must be evaluated in clinical trials. We also note that the improved efficacy 
of NR with respect to NAM has been observed in diseases and conditions in which the NR kinase pathway is induced and/or the NAM salvage expression is diminished(46-48).

In summary, these are the first data that describe the $\mathrm{NAD}^{+}$metabolome in human liver. The data indicate that two agents, NA and NR, which are protective in rodent models of liver disease are depressed in ArLD, that the NAD ${ }^{+}$metabolome is depressed in ArLD in ways that correlate with functional impairment of defense against infection. In combination with human safety and pre-clinical efficacy data of NA and NR $(31,37(49,50)$, these data provide the rationale for the investigation of vitamin B3 supplementation in ArLD. 


\section{References}

1. Fleming KM, Aithal GP, Solaymani-Dodaran M, Card TR, West J. Incidence and prevalence of cimhosis in the United Kingdom, 1992-2001: a general population-based study. J Hepatol 2008;49:732-738.

2. Park SH, Kim CH, Kim DJ , Park J H, Kim TO, Yang SY, Moon YS, et al. Prevalence of alcoholic liver disease among Korean adults: results from the fourth Korea National Health and Nutrition Examination Survey, 2009. Subst Use Misuse 2011;46:1755-1762.

3. Jepsen P, Vilstup $H$, Sørensen HT. Alcoholic cirhosis in Denmark - populationbased incidence, prevalence, and hospitalization rates between 1988 and 2005: a descriptive cohort study. BMC Gastroenterol 2008;8:3.

4. Lucey MR, Mathurin P, Morgan TR. Alcoholic hepatitis. N Engl J Med 2009;360:2758-2769.

5. Baptista AB, L; De Groote, J et al. . Alcoholic Liver Disea se: Morphological Manifestations. Review by Intemational G roup. The Lancet. 1981;1:707-711.

6. Hughes E, Hopkins LI, Parker R. Survival from alc o holic hepa titis has not improved over time. PLoS O ne 2018;13:e0192393.

7. Glavind E, Aagaard NK, Grønbæk H, Møller HJ , Omtoft NW, Vilstrup H, Thomsen $\mathrm{KL}$. Alc oholic Hepatitis Markedly Decreases the Capacity for Urea Synthesis. PLoS One 2016;11:e0158388.

8. Mantena SK, King AL, Andringa KK, Eccleston HB, Bailey SM. Mitochondrial dysfunction and oxidative stress in the pathogenesis of alcohol- and obesity-induced fatty liver diseases. Free Radic Biol Med 2008;44:1259-1272.

9. Belenky P, Bogan KL, Brenner C. NAD+metabolism in health and disease. Trends in Biochemic al Sciences 2007;32:12-19.

10. Trammell SA, Brenner C. Targeted, LCMS-based Metabolomics for Quantitative Measurement of NAD(+) Metabolites. Comput Struct Biotec hnolJ 2013;4:e201301012.

11. L Q, Xie G, Zhang W, Zhong W, Sun X, Tan X, J ia W, et al. Dietary nic otinic acid supplementation ameliorates chronic alcohol-induced fatty liver in rats. Alcohol Clin Exp Res 2014;38:1982-1992.

12. Chemick GR, Leevy CM. The effect of ethanol metabolism on levels on oxidized and reduced nic otinamide-adenine dinucleotide in liver, kidney, and heart. Biochim Biophys Acta 1965;107:29-37.

13. Zakhari S, Li TK. Deteminants of alc ohol use and abuse: Impact of quantity and frequency pattems on liver disea se. Hepatology 2007;46:2032-2039.

14. Shepard BD, Tuma PL. Alcohol-induced protein hyperacetylation: mechanisms and consequences. World J Gastroenterol 2009;15:1219-1230.

15. Picklo MJ. Ethanol intoxication increases hepatic $\mathrm{N}$-lysyl protein acetylation. Bioc hem Biophys Res Commun 2008;376:615-619.

16. You M, Matsumoto M, Pacold CM, Cho WK, Crabb DW. The role of AMPactivated protein kinase in the action of ethanol in the liver. Gastroenterology 2004;127:1798-1808. 
17. Shen Z, Liang X, Rogers CQ, Rideout D, You M. Involvement of adiponectin-SIRT1AMPK signaling in the protective action of rosiglitazone against alcoholic fatty liver in mice. Am J Physiol Gastrointest Liver Physiol 2010;298:G 364-374.

18. Lieber CS, Leo MA, Wang X, Decarli LM. Effect of chronic alcohol consumption on Hepatic SIRTI and PGC-1alpha in rats. Biochem Biophys Res Commun 2008;370:4448.

19. Tummala KS, Gomes AL, Yilmaz M, Grana O, Bakin L, Ruppen I, Ximenez-Embun $P$, et al. Inhibition of de novo $\mathrm{NAD}(+)$ synthesis by oncogenic URI causes liver tumorigenesis through DNA damage. Cancer Cell 2014;26:826-839.

20. Yin H, Hu M, Liang X, Ajmo J M, L X, Bataller R, Odena G, et al. Deletion of SIRTI from hepatocytes in mice disnupts lipin-1 signaling and aggravates alcoholic fatty liver. Gastroenterology 2014;146:801-811.

21. Punushotham A, Schug TT, Xu Q, Surapureddi S, Guo X, L X. Hepatocyte-specific deletion of SIRT1 alters fatty acid metabolism and results in hepatic steatosis and inflammation. Cell Metab 2009;9:327-338.

22. Pfluger PT, Herranz D, Velasco-Miguel S, Serrano M, Tschöp MH. Sirtl protects against high-fat diet-induced metabolic damage. Proc Natl Acad Sci U S A 2008;105:9793-9798.

23. Bogan KL, Brenner C. Nic otinic acid, nic otina mide, and nic otinamide riboside: A molecular evaluation of NAD + precursor vitamins in human nutrition. Annual Review of Nutrition 2008;28:115-130.

24. Biega nowski $P$, Brenner C. Disc overies of nic otina mide riboside as a nutrient and conserved NRK genes establish a preiss-handler independent route to NAD+ in fungi and humans. Cell 2004;117:495-502.

25. Trammell SA, Weidemann BJ, Chadda A, Yorek MS, Holmes A, Coppey LJ, Obrosov A, et al. Nic otinamide Riboside Opposes Type 2 Diabetes and Neuropathy in Mice. Sci Rep 2016;6:26933.

26. Wang S, Wan T, Ye M, Qiu Y, Pei L, Jiang R, Pang N, et al. Nic otinamide riboside attenuates alcohol induced liver injuries via activation of SirT1/PGClalpha/mitoc hondrial biosynthesis pathway. Redox Biol 2018;17:89-98.

27. Jiang R, Zhou Y, Wang S, Pang N, Huang Y, Ye M, Wan T, et al. Nic otinamide riboside protects a ga inst liver fibrosis induced by $\mathrm{CCl} 4$ via regulating the acetylation of Smads signa ling pathway. Life Sci 2019;225:20-28.

28. Ear PH, Chadda A, Gumusoglu SB, Schmidt MS, Vogeler S, Malic oat J, Kadel J , et al. Matemal Nicotinamide Riboside Enhances Postpartum Weight Loss, J uvenile Offspring Development, and Neurogenesis of Adult Offspring. Cell Rep 2019;26:969-983 e964.

29. Sambeat A, Ratajczak J, J offraud M, Sanchez-Garcia J L, Giner MP, Valsesia A, Giroud-Gerbetant J, et al. Endogenous nicotinamide riboside metabolism protects a gainst diet-induced liver damage. Nat Commun 2019;10:4291.

30. Altamirano J, Miquel R, Katooniza deh A, Abraldes J G, Duarte-Rojo A, Louvet A, Augustin S, et al. A histologic scoring system for prognosis of patients with alcoholic hepa titis. G a stroenterology 2014;146:1231-1239.e1231-1236.

31. Cederbaum Al, Lu Y, Wu D. Role of oxidative stress in alcohol-induced liver injury. Arch Toxic ol 2009;83:519-548. 
32. Trevejo-Nunez G, Kolls J K, de Wit M. Alcohol Use As a Risk Factor in Infections and Healing: A Clinician's Perspective. Alcohol Res 2015;37:177-184.

33. Trammell SA, Schmidt MS, Weidemann BJ , Redpath P, J aksch F, Dellinger RW, Li $Z$, et al. Nic otinamide riboside is uniquely and orally bioavailable in mice and humans. Nat Commun 2016;7:12948.

34. Liu L, Su X, Quinn WJ, 3rd, Hui S, Krukenberg K, Frederick DW, Redpath P, et al. Quantitative Analysis of NAD Synthesis-Breakdown Fluxes. Cell Metab 2018;27:1067-1080 e1065.

35. Fan R, Cui J, Ren F, Wang Q, Huang Y, Zhao B, Wei L, et al. Overexpression of NRK1 ameliorates diet- and age-induced hepatic steatosis and insulin resistance. Bioc hem Biophys Res Commun 2018;500:476-483.

36. Brenner C. Metabolism: Targeting a fat-accumulation gene. Nature 2014;508:194-195.

37. Moreau R, Perianin A, Arroyo V. Review of Defective NADPH Oxidase Activity and Myeloperoxida se Relea se in Neutrophils From Patients With Cimhosis. Front Immunol 2019;10:1044.

38. Hemandez-Munoz R, Diaz-Munoz M, Lopez V, Lopez-Barrera F, Yanez L, Vidrio S, Aranda-Fraustro $A$, et al. Balance between oxidative damage and proliferative potential in an experimental rat model of CCl4-induced cimhosis: protective role of a denosine administration. Hepatology 1997;26:1100-1110.

39. Boussif A, Rolas L, Weiss E, Bouriche H, Moreau R, Perianin A. Impaired intrac ellular signaling, myeloperoxidase release and bactericidal activity of neutrophils from patients with a lc oholic cirhosis. J Hepatol 2016;64:1041-1048.

40. Wells JT, Sa id A, Agni R, Tome S, Hughes S, Dureja P, Lucey MR. The impact of acute alcoholic hepatitis in the explanted recipient liver on outcome after liver transpla nta tion. Liver Transpl 2007;13:1728-1735.

41. Majumdar SK, Dias N, Aps EJ. Relationship between hepatic histology and conventional biochemical liver function test in chronic alcoholic patients. Drug Alcohol Depend 1991;28:211-214.

42. Louvet A, Naveau S, Abdelnour M, Ramond MJ, Diaz E, Fartoux L, Dharancy S, et al. The Lille model: a new tool for therapeutic strategy in patients with severe alcoholic hepatitis treated with steroids. Hepatology 2007;45:1348-1354.

43. Dou X, Shen C, Wang Z, L S, Zhang X, Song Z Protection of nic otinic acid against oxidative stress-induced cell death in hepatocytes contributes to its beneficial effect on alc ohol-induced liver injury in mice.J Nutr Biochem 2013;24:1520-1528.

44. Kolovou GD, Salpea KD, Mihas C, Malakos I, Kafaltis N, Bilianou HG, Adamopoulou EN, et al. Comparison of simvastatin and nic otinic a cid administration in alc ohol-trea ted Wista r rats. Hellenic J Cardiol 2008;49:79-85.

45. Dollerup OL, Christensen B, Svart M, Schmidt MS, Sulek K, Ringga ard S, Sto dkildeJorgensen $\mathrm{H}$, et al. A randomized placebo-controlled clinical trial of nic otinamide riboside in obese men: safety, insulin-sensitivity, and lipid-mobilizing effects. Am J Clin Nutr 2018;108:343-353.

46. Diguet N, Trammell SAJ , Tannous C, Deloux R, Piquereau J, Mougenot N, Gouge A, et al. Nicotinamide Riboside Preserves Cardiac Function in a Mouse Model of Dilated Cardiomyopathy. Circulation 2018;137:2256-2273. 
47. Vaur P, Brugg B, Meric skay M, Li Z, Schmidt MS, Vivien D, Orset C, et al. Nicotinamide riboside, a form of vitamin B3, protects aga inst excitotoxic ity-induced axonal degeneration. FASEBJ 2017;31:5440-5452.

48. Liu HW, Smith CB, Schmidt MS, Cambronne XA, Cohen MS, Migaud ME, Brenner $C$, et al. Phamacological bypass of $N A D(+)$ salvage pathway protects neurons from chemotherapy-induced degeneration. Proc Natl Acad Sci U S A 2018;115:10654-10659.

49. Conze DB, Brenner C, Kruger CL. Safety and Metabolism of Long Term Administration of Niagen ${ }^{\circledR}$ (Nicotinamide Riboside Chloride) in Healthy Overweight Adults. Sci Rep 2019;9:9772.

50. Elhassan YS, Kluckova K, Fletcher RS, Schmidt MS, Garten A, Doig CL, Cartwright DM, et al. Nicotinamide Riboside Augments the Aged Human Skeletal Muscle NAD(+) Metabolome and Induces Transcriptomic and Anti-inflammatory Signatures. Cell Rep 2019;28:1717-1728 e1716. 


\section{Acknowledgment}

The authors would like to thank Noah Fluharty of the University of lowa for advice and assistance in editing and formatting.

\section{Figure legends}

FIG. 1. NAD co-enzymes and precursors are depressed in ArLD liver samples. A, B, NAD'; C, D NA; E, F NADP ${ }^{+}$; G, H NR. Data are shown as mean and standard error of mean. ${ }^{*} p<0.05$ by student's test ${ }^{* * *} p<0.001$ by student's test.

FIG. 2. Histologically severe alcoholic steatohepatitis further depresses the liver NAD metabolome with respect to non-severe alcoholic steatohepatitis. Steatohepatitis was described histologically as per the scoring system described by Altamirano et al (30), and severe disease in this cohort defined as a cut-off of three points or greater. Data are shown as mean and SEM. * $p<0.05$ by two-way ANOVA.

FIG. 3. Depressed hepatic NAD+correlates with higher bilirubin in human patients. ${ }^{*} p<0.05$ by linear regression.

FIG. 4. Indications of depressed neutrophil infection defenses in ArLD liver tissue. Data are shown as mean and SEM *** $<<0.01$ by student's t-test.

FIG. 5. Association between myeloperoxidase activity and $\mathrm{NAD}^{+}$content in liver tissue. ${ }^{* * *} \mathrm{p}<0.001$ by linear regression. 


\section{Data Accessibility Statement}

The datasets generated during and/or analyzed during the current study are available from the corresponding author on request.

\section{Conflicts of interest:}

RP: no conflicts of interest to declare

MS: no conflicts of interest to declare

OC: no conflicts of interest to declare

BG: no conflicts of interest to declare

CB: Charles Brenner developed intellectual property that has been licensed and developed by ChromaDex. He holds stock in ChromaDex and consults for ChromaDex and Cytokinetics. 
TABLE 1: CLINICAL CHARACTERISTICS OF HUMAN LIVER SAMPLES

\begin{tabular}{|c|c|c|c|c|c|c|c|c|c|c|c|c|c|}
\hline & \multicolumn{2}{|c|}{$\begin{array}{c}\text { Normal } \\
n=14\end{array}$} & \multicolumn{2}{|c|}{$\begin{array}{l}\text { PBC } \\
n=5\end{array}$} & \multicolumn{2}{|c|}{$\begin{array}{l}\text { PSC } \\
n=5\end{array}$} & \multicolumn{2}{|c|}{$\begin{array}{c}\text { NASH } \\
n=5\end{array}$} & \multicolumn{2}{|c|}{$\begin{array}{c}\text { All non-ArLD } \\
\text { disease } \\
n=15\end{array}$} & \multicolumn{2}{|c|}{$\begin{array}{l}\text { ArLD } \\
n=43\end{array}$} & \multirow{2}{*}{$\begin{array}{c}\mathbf{p} \\
\text { (one-way } \\
\text { ANOVA) }\end{array}$} \\
\hline & Mean & SD & Mean & SD & Mean & SD & Mean & SD & Mean & SD & Mean & SD & \\
\hline $\begin{array}{c}\text { Age } \\
\text { (years) }\end{array}$ & 62.5 & 7.1 & 61.4 & 10.8 & 49.0 & 19.0 & 56.6 & 7.9 & 55.7 & 13.5 & 56.4 & 9.6 & 0.105 \\
\hline $\begin{array}{c}\text { BMI } \\
\left(\mathrm{kg} / \mathrm{m}^{2}\right)\end{array}$ & 30.4 & 6.5 & 26.7 & 3.0 & 24.4 & 2.7 & 32.5 & 32.4 & 27.8 & 4.9 & 27.6 & 4.3 & 0.028 \\
\hline $\begin{array}{l}\text { Random } \\
\text { glucose } \\
\text { (mmol/L) }\end{array}$ & 4.80 & 1.0 & 4.92 & 0.9 & 5.36 & 1.6 & 14.1 & 6.5 & 8.1 & 5.7 & 7.6 & 4.1 & 0.005 \\
\hline $\begin{array}{l}\mathrm{HbA1c} \\
(\mathrm{mol} / \mathrm{mm} \\
\text { ol) }\end{array}$ & 58.7 & 6.4 & 23.0 & 7.1 & 30.7 & 4.0 & 46.7 & 19.1 & 34.8 & 15.0 & 30.1 & 11.8 & 0.002 \\
\hline $\begin{array}{l}\text { AST } \\
(\mathrm{U} / \mathrm{L})\end{array}$ & 29.0 & 9.6 & 87.5 & 87.5 & 93.8 & 45.3 & 44.0 & 14.8 & 79.3 & 39.4 & 54.6 & 27.5 & 0.005 \\
\hline $\begin{array}{l}\text { ALT } \\
(\mathrm{U} / \mathrm{L})\end{array}$ & 31.4 & $\begin{array}{c}31 . \\
3\end{array}$ & 47.6 & 47.6 & 75.8 & 52.9 & 21.4 & 5.8 & 48.3 & 37.7 & 39.5 & 39.4 & 0.167 \\
\hline $\begin{array}{l}\text { Bilirubin } \\
\text { (mmol/L) }\end{array}$ & 9.7 & 5.4 & 57.2 & 57.2 & 97.4 & 59.9 & 50.8 & 44.4 & 68.5 & 49.4 & 64.1 & 71.1 & 0.038 \\
\hline
\end{tabular}


TABLE 2: QUANTITATIVE ANALYSIS OF THE NAD METABOLOME IN LIVER DISEASE

$\begin{array}{cccccccc} & \text { Normal } & \text { PBC } & \text { PSC } & \text { NASH } & \text { ArLD } & \begin{array}{c}\text { ALD } \\ \text { without } \\ \text { ASH }\end{array} & \begin{array}{c}\text { ALD } \\ \text { with ASH }\end{array} \\ \text { NAD } & 616 & 524 & 550 & 542 & 432 & 462 & 322 \\ \text { NADP } & 236 & 184 & 186 & 149 & 99 & 106 & 73 \\ \text { NMN } & 5.71 & 4.84 & 4.70 & 4.43 & 3.93 & 3.93 & 2.89 \\ \text { ADPR } & 202 & 180 & 98.2 & 339 & 178 & 188 & 141 \\ \text { cADPR } & 1.83 & 2.08 & 2.15 & 2.13 & 1.71 & 1.76 & 1.29 \\ \text { NR } & 19.6 & 13.6 & 27.1 & 6.5 & 4.0 & 3.23 & 7.27 \\ \text { Nam } & 155 & 170 & 212 & 155 & 165 & 164 & 142 \\ \text { NA } & 5.74 & 2.37 & 3.69 & 1.85 & 1.94 & 2.21 & 1.38 \\ \text { MeNam } & 15.8 & 27.3 & 30.0 & 28.7 & 36.7 & 36.6 & 35.1 \\ \text { Me4PY } & 4.33 & 3.83 & 4.41 & 2.75 & 3.45 & 3.61 & 2.86 \\ \text { Me2PY } & 25.1 & 19.8 & 24.1 & 14.9 & 21.9 & 23.0 & 17.8\end{array}$

Metabolites are expressed as mean values in $\mu \mathrm{M}$. P values by one-way ANOVA. 
A

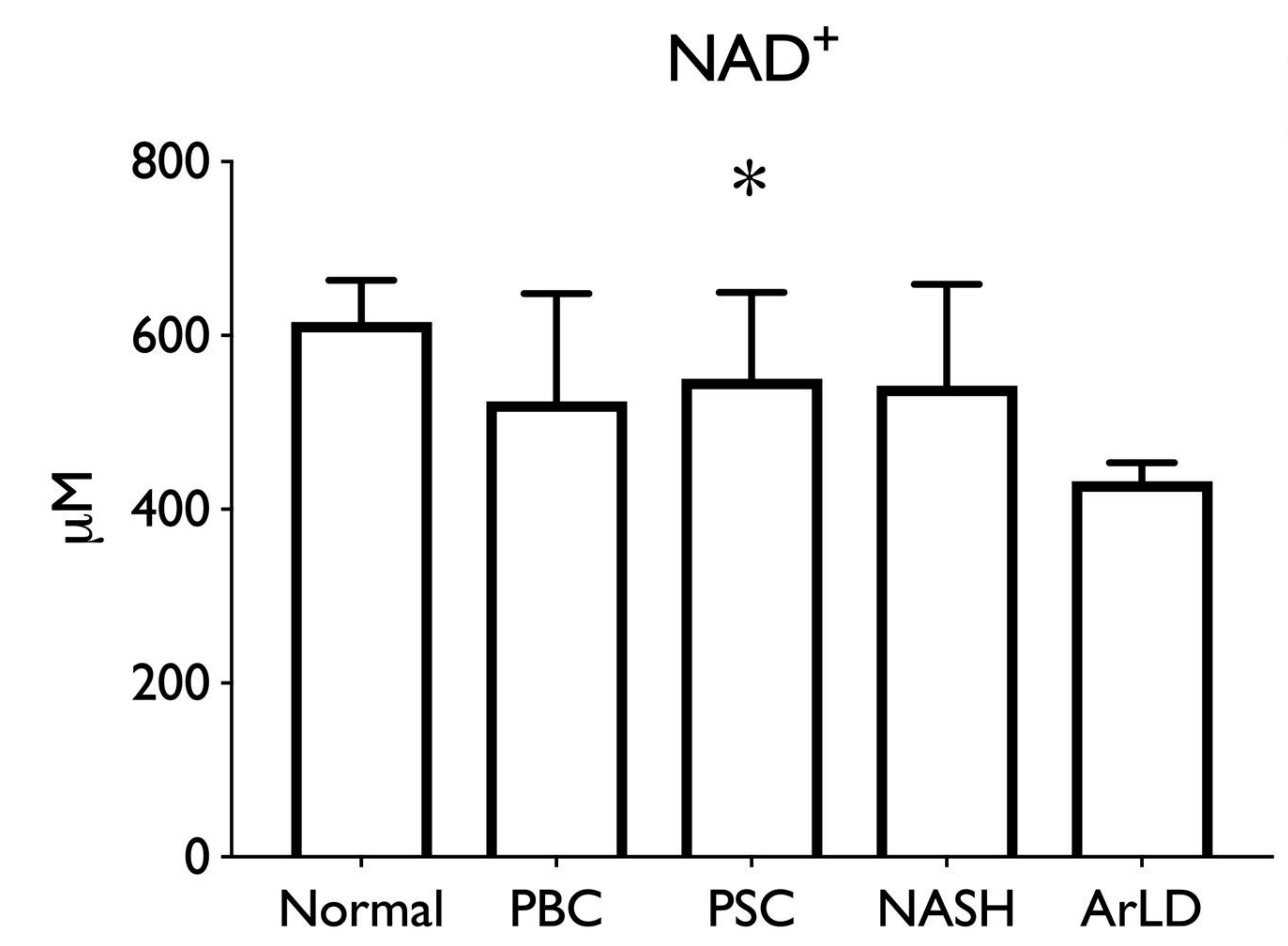

NA

C

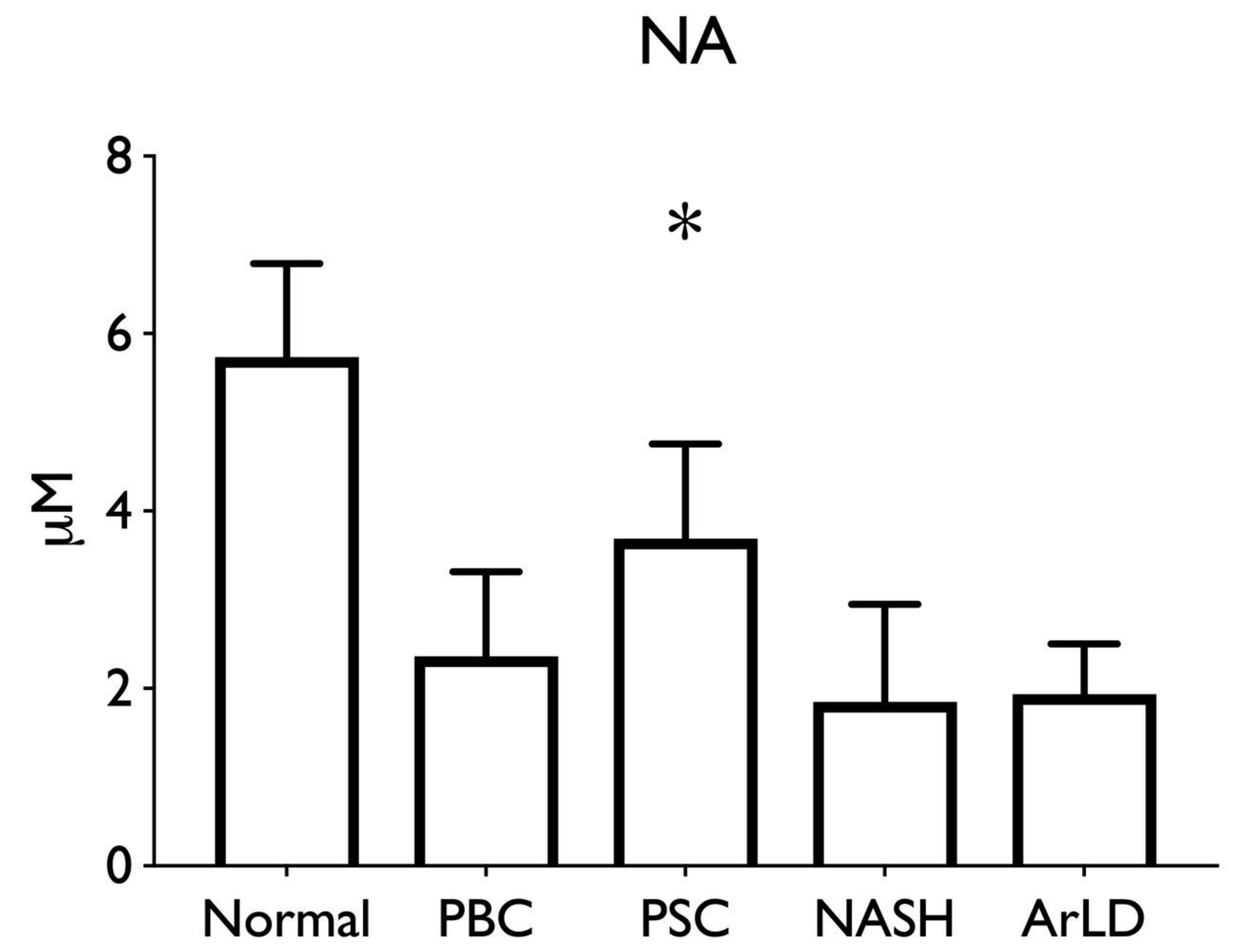

E

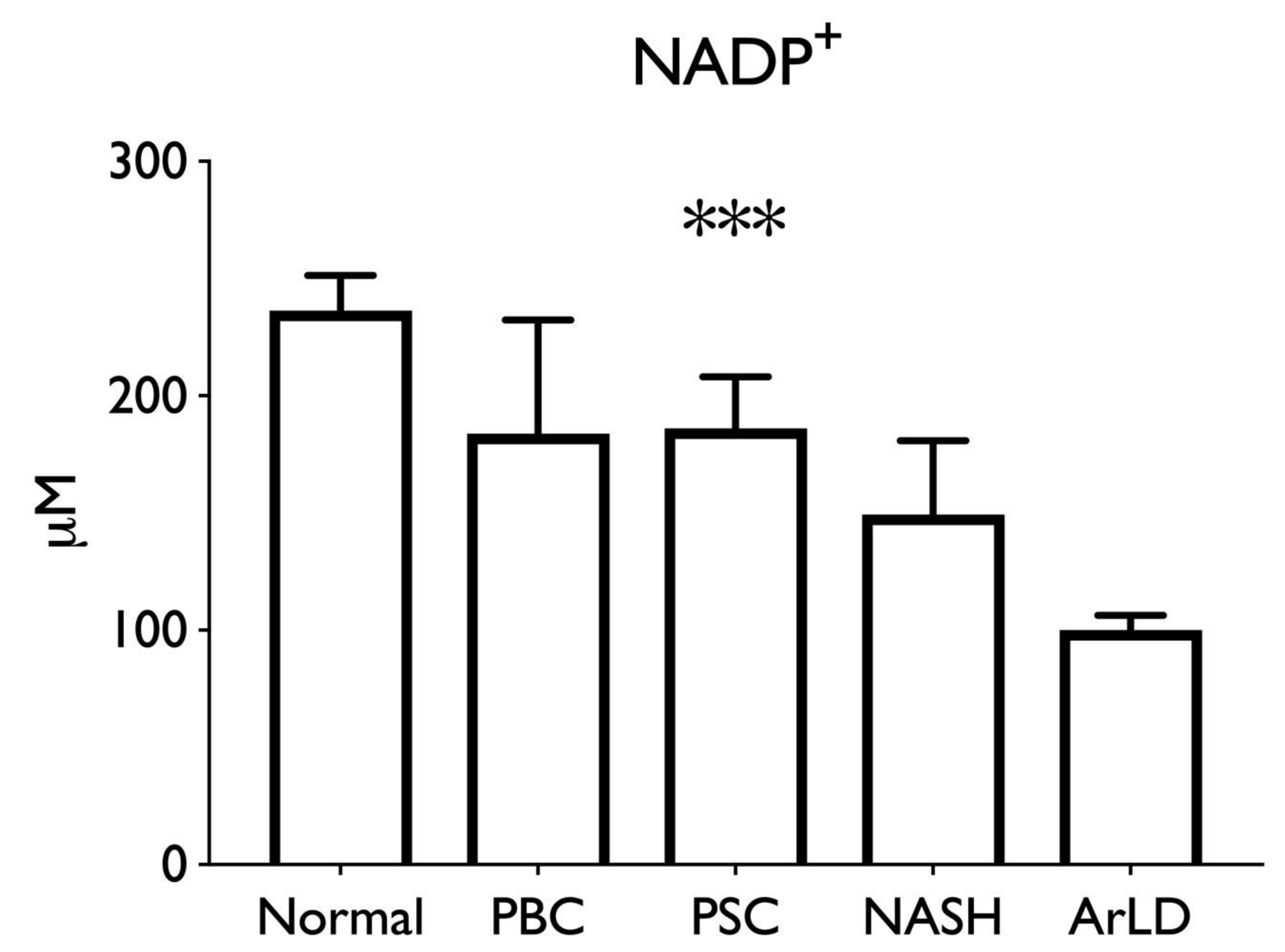

NR

G

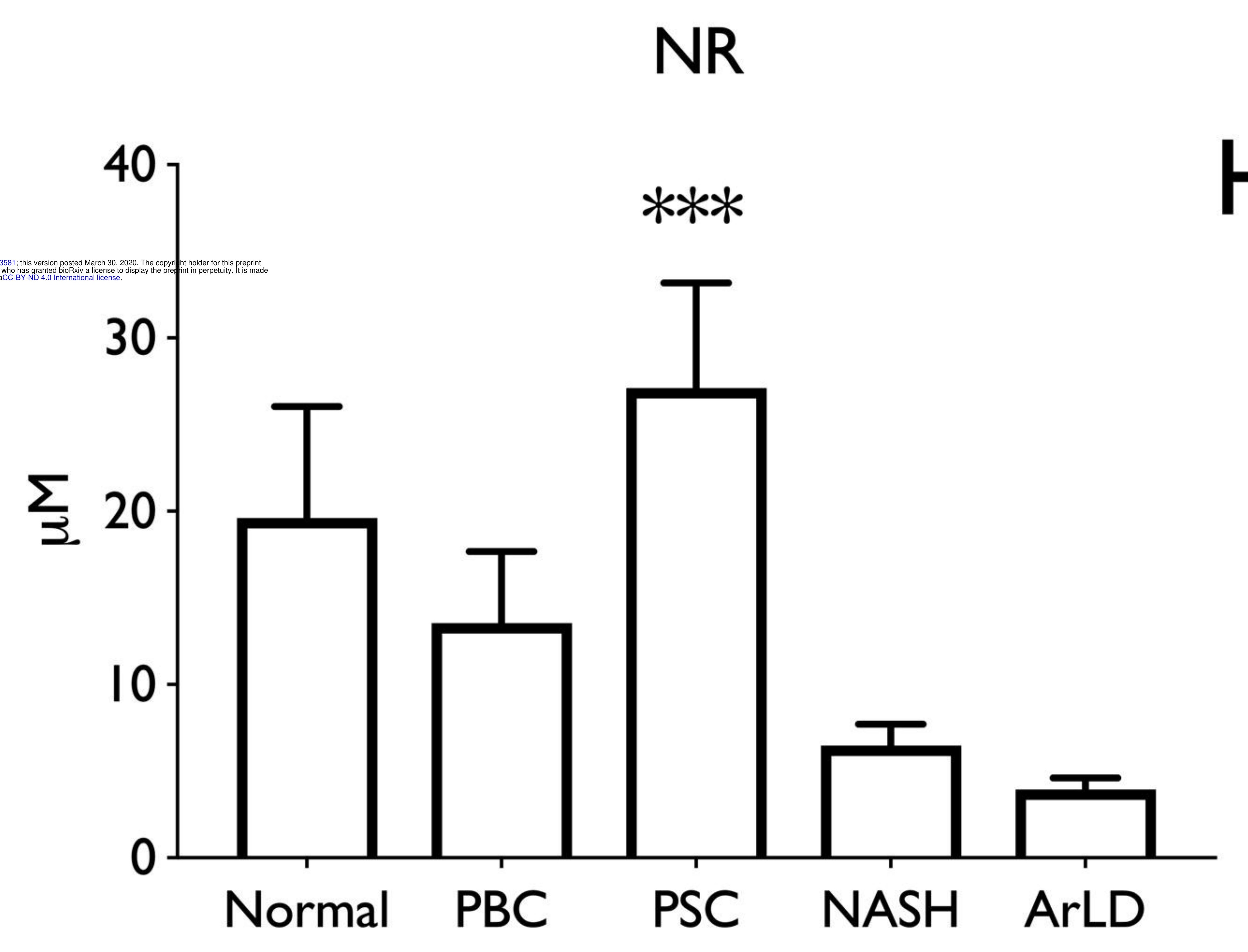

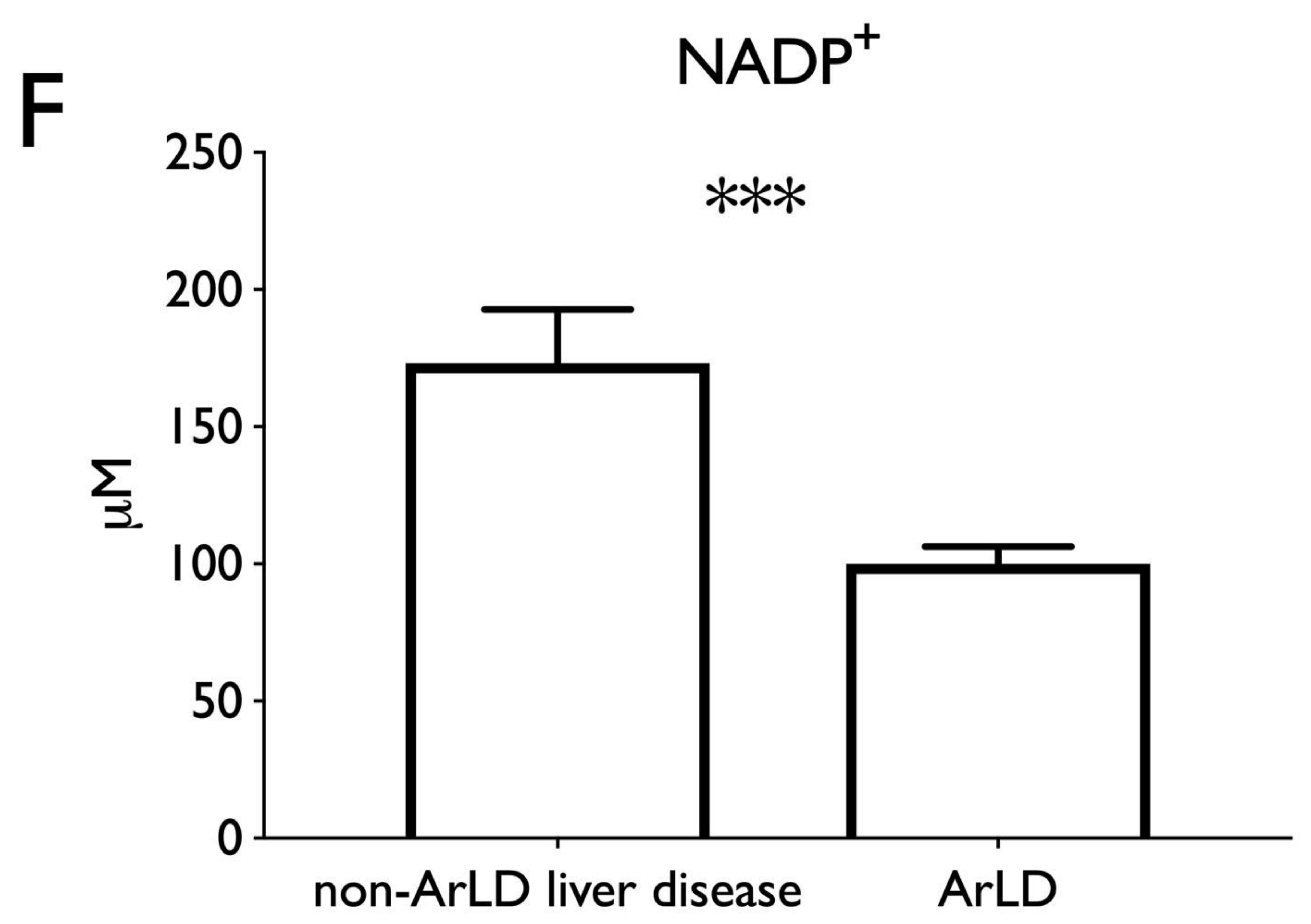

B

$\mathrm{NAD}^{+}$

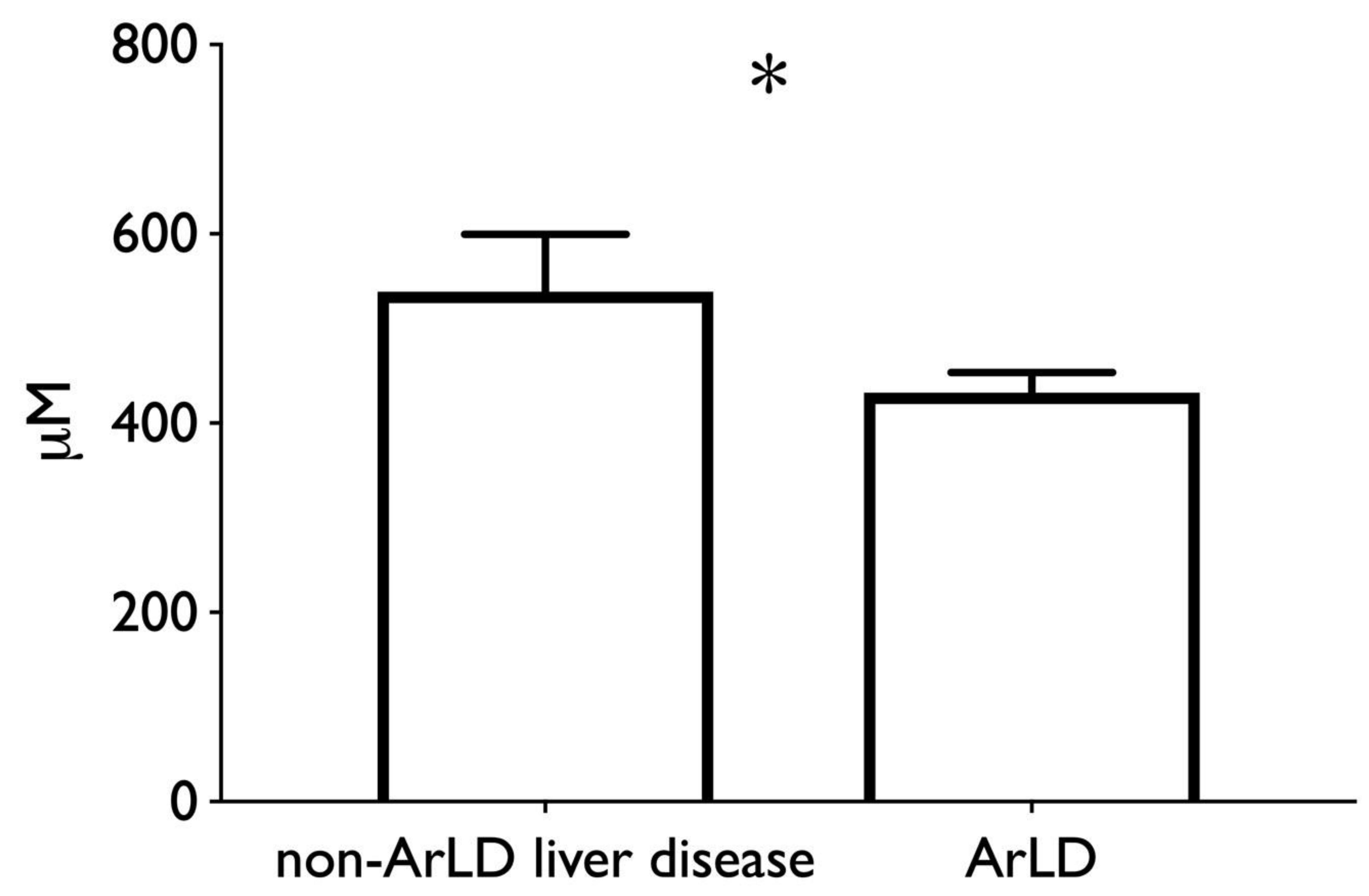

D

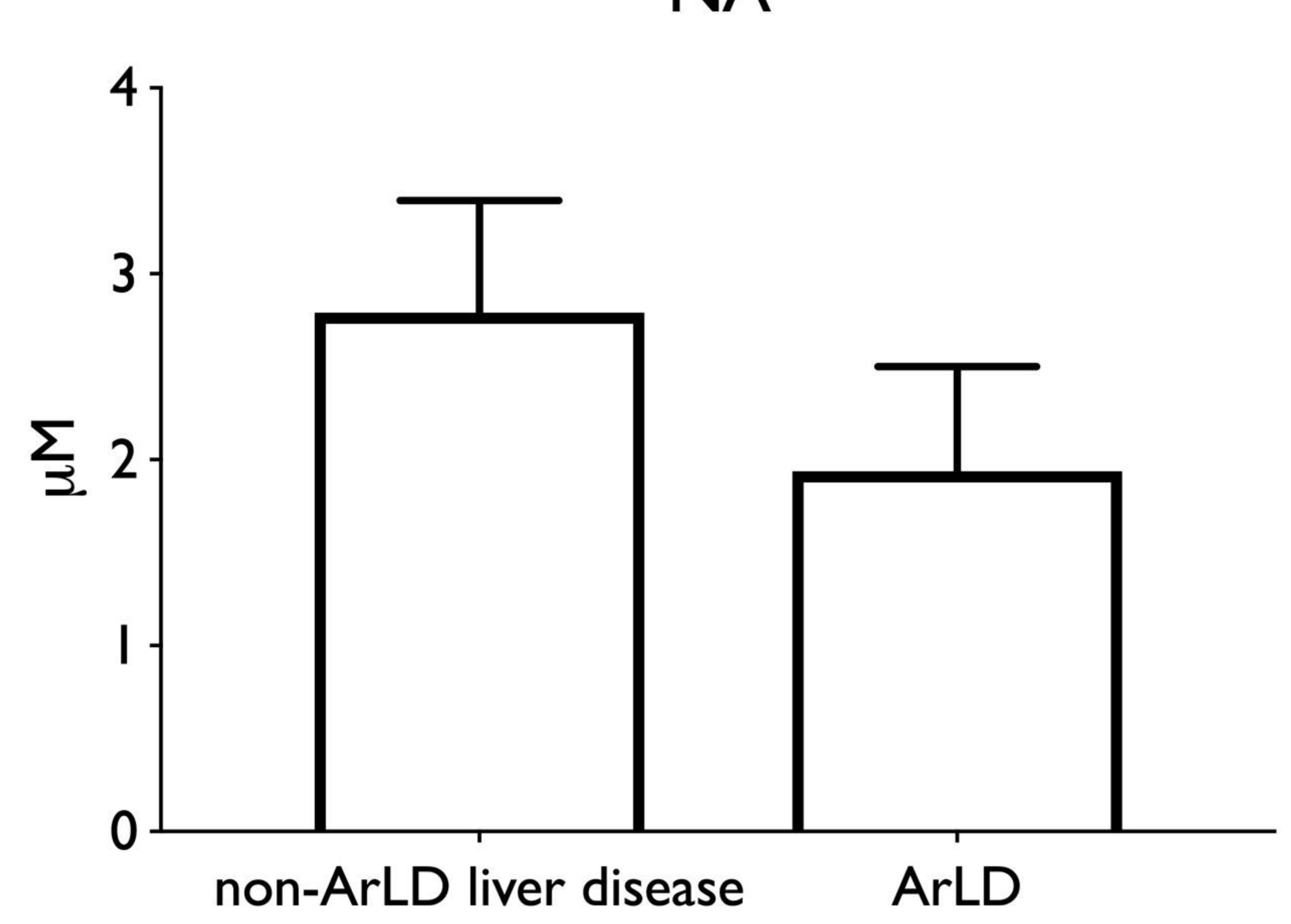

NA

NR

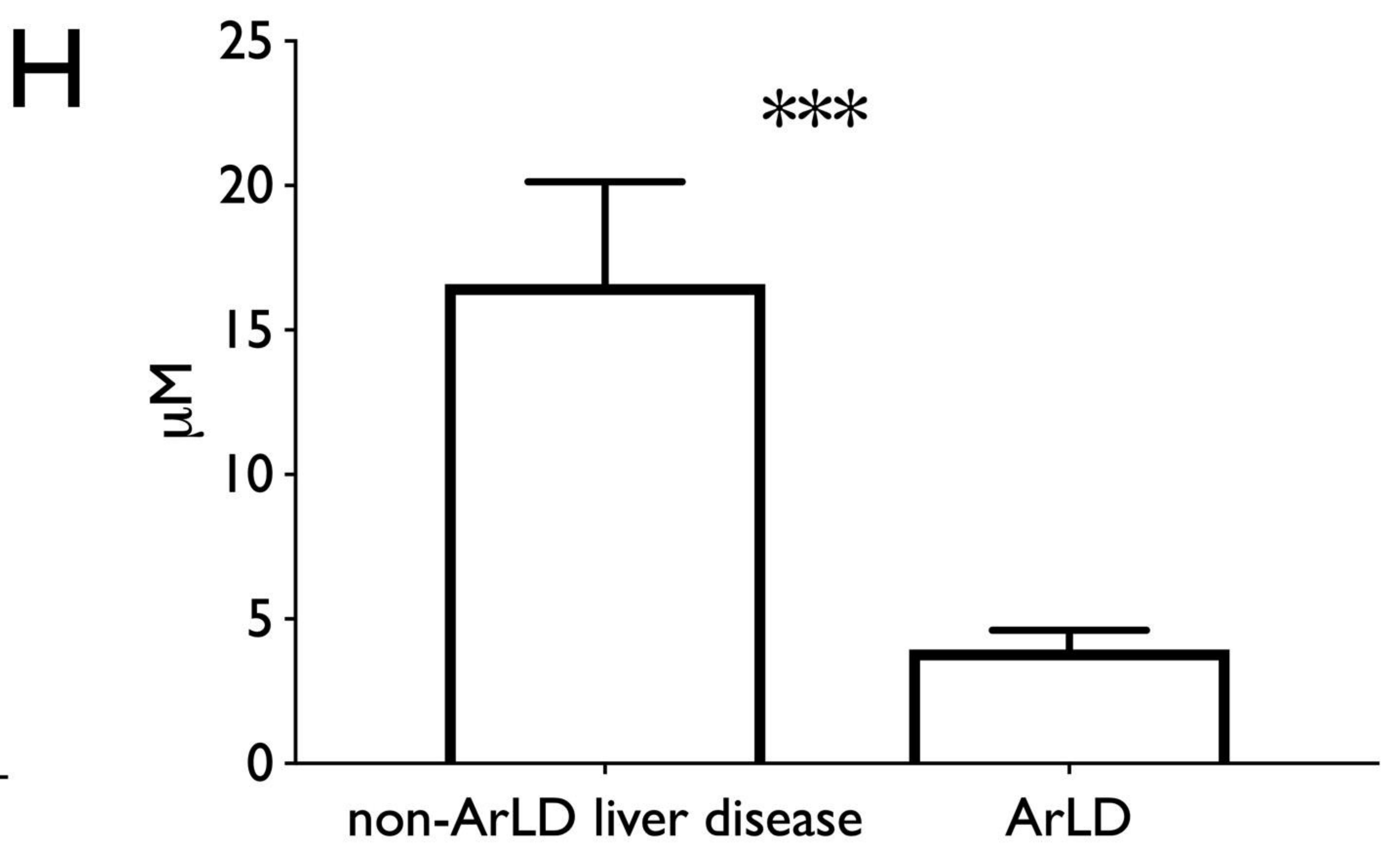




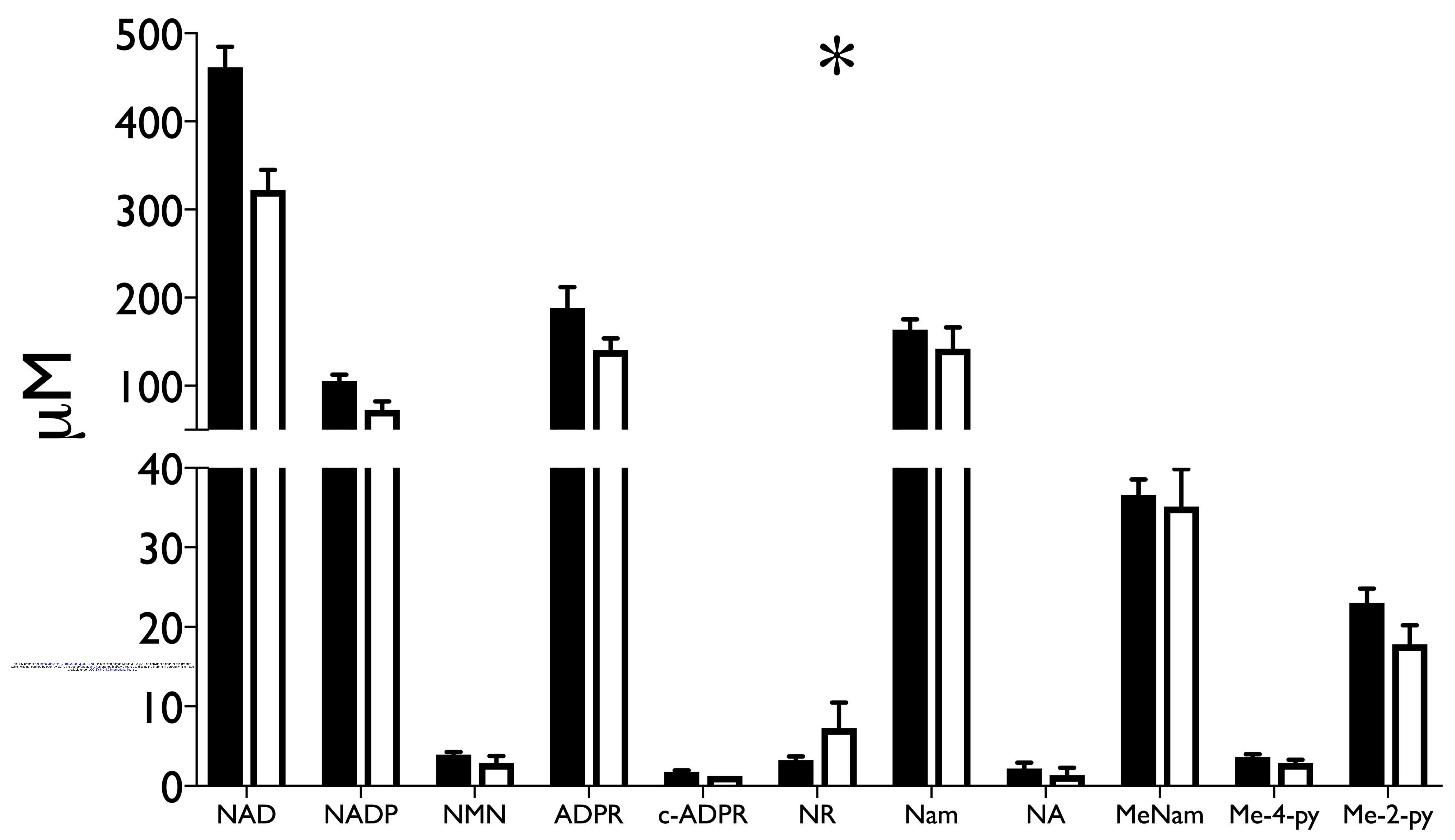


Bilirubin

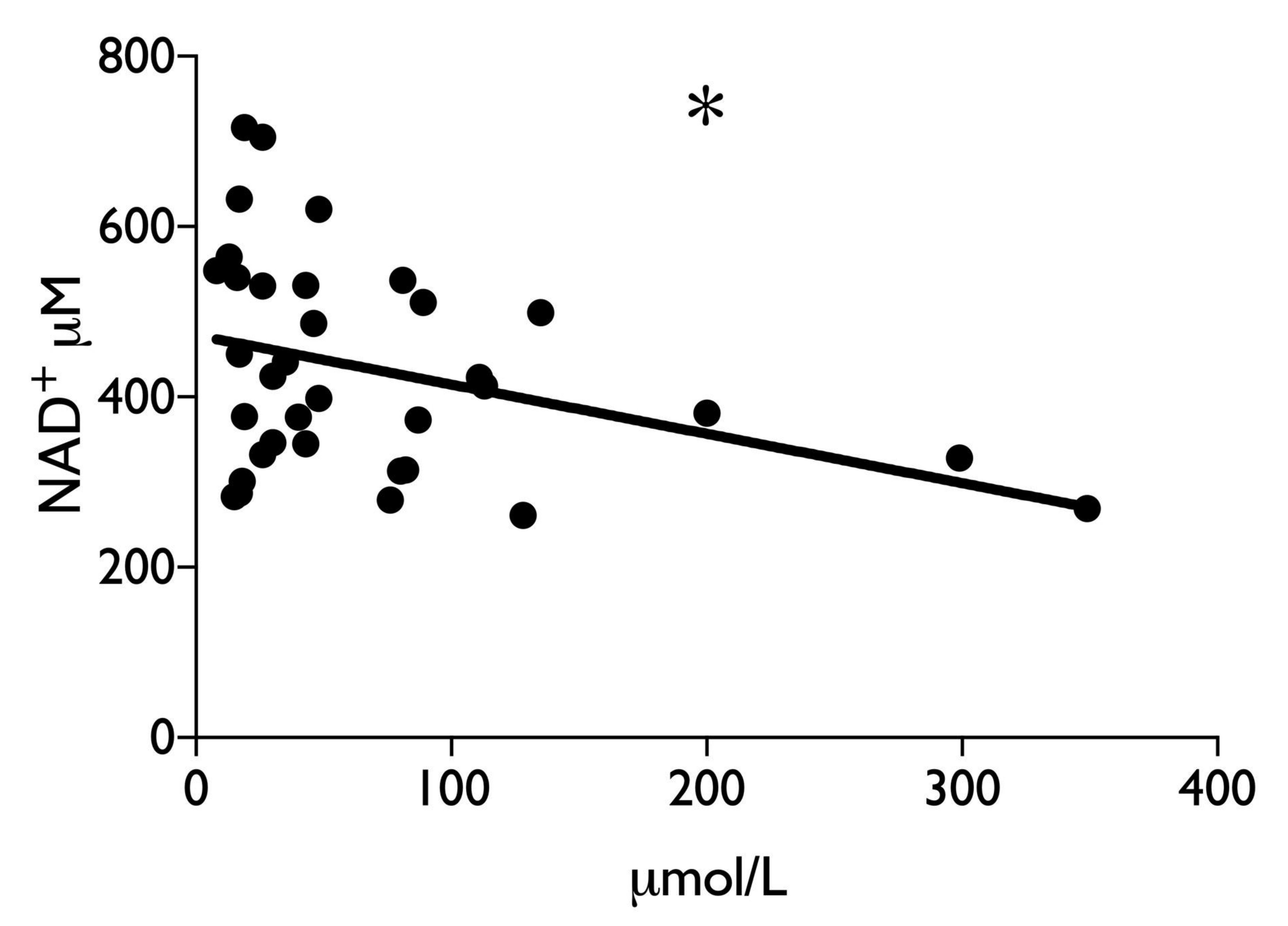

HbAlc

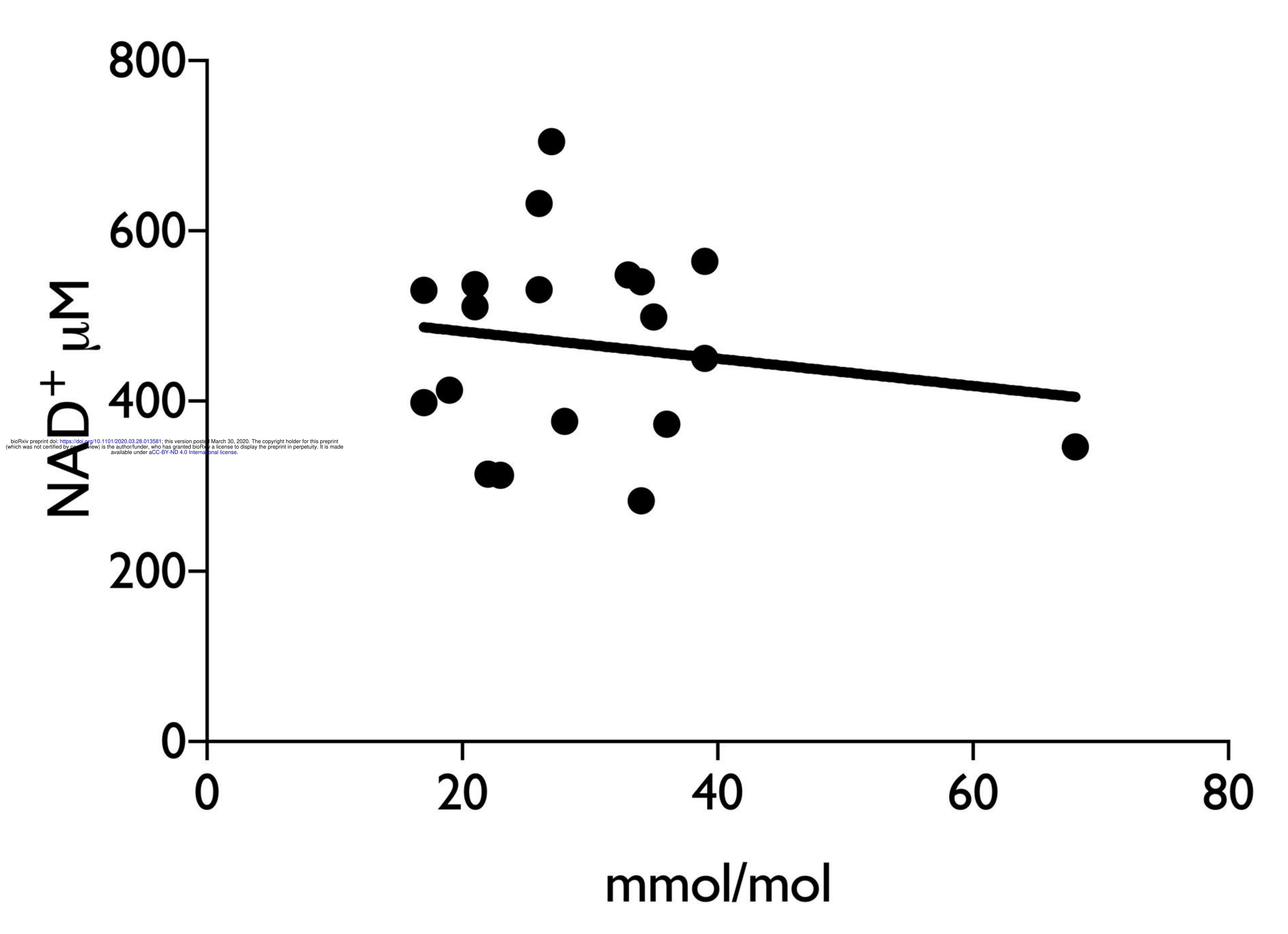

ALT

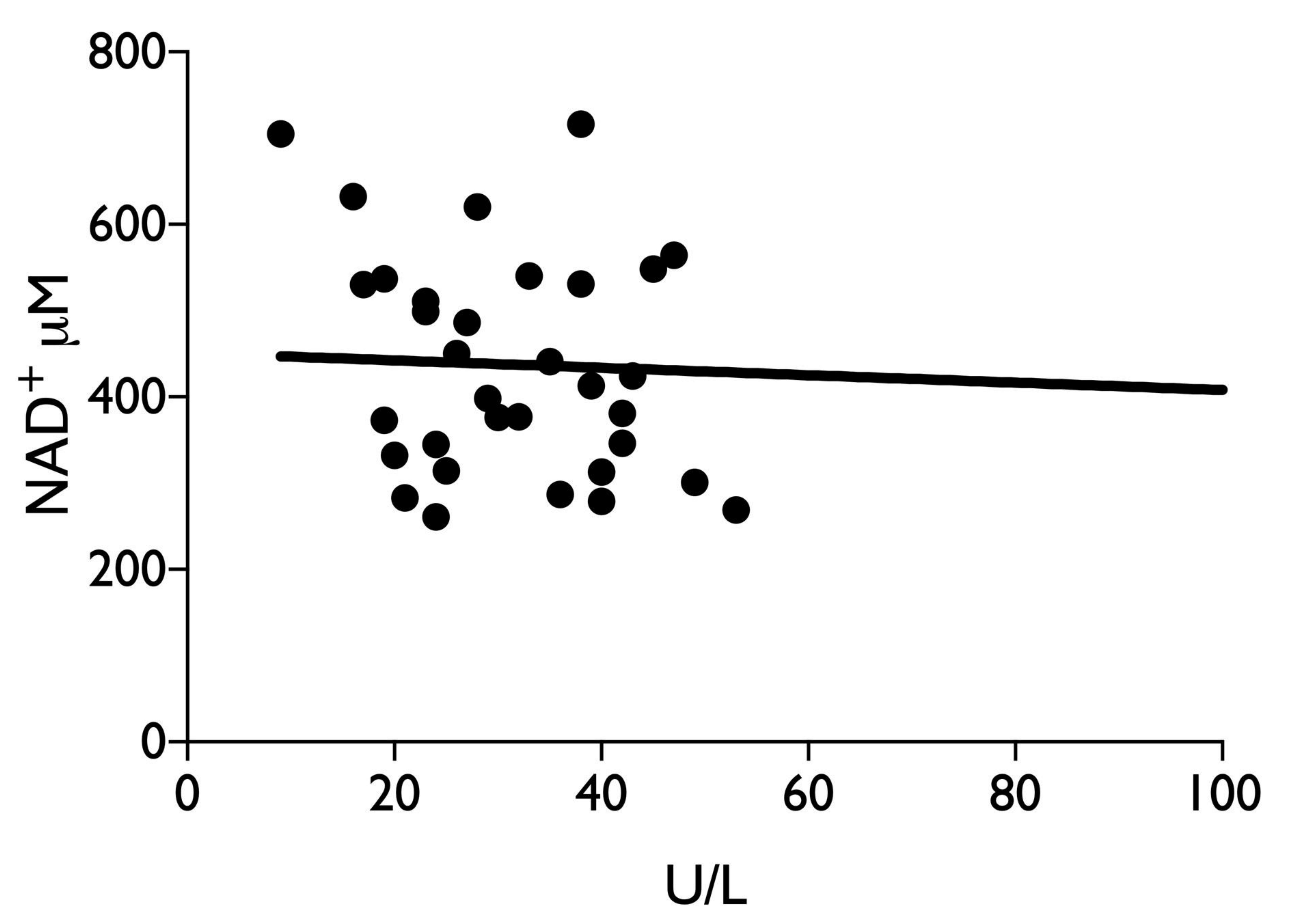

Age

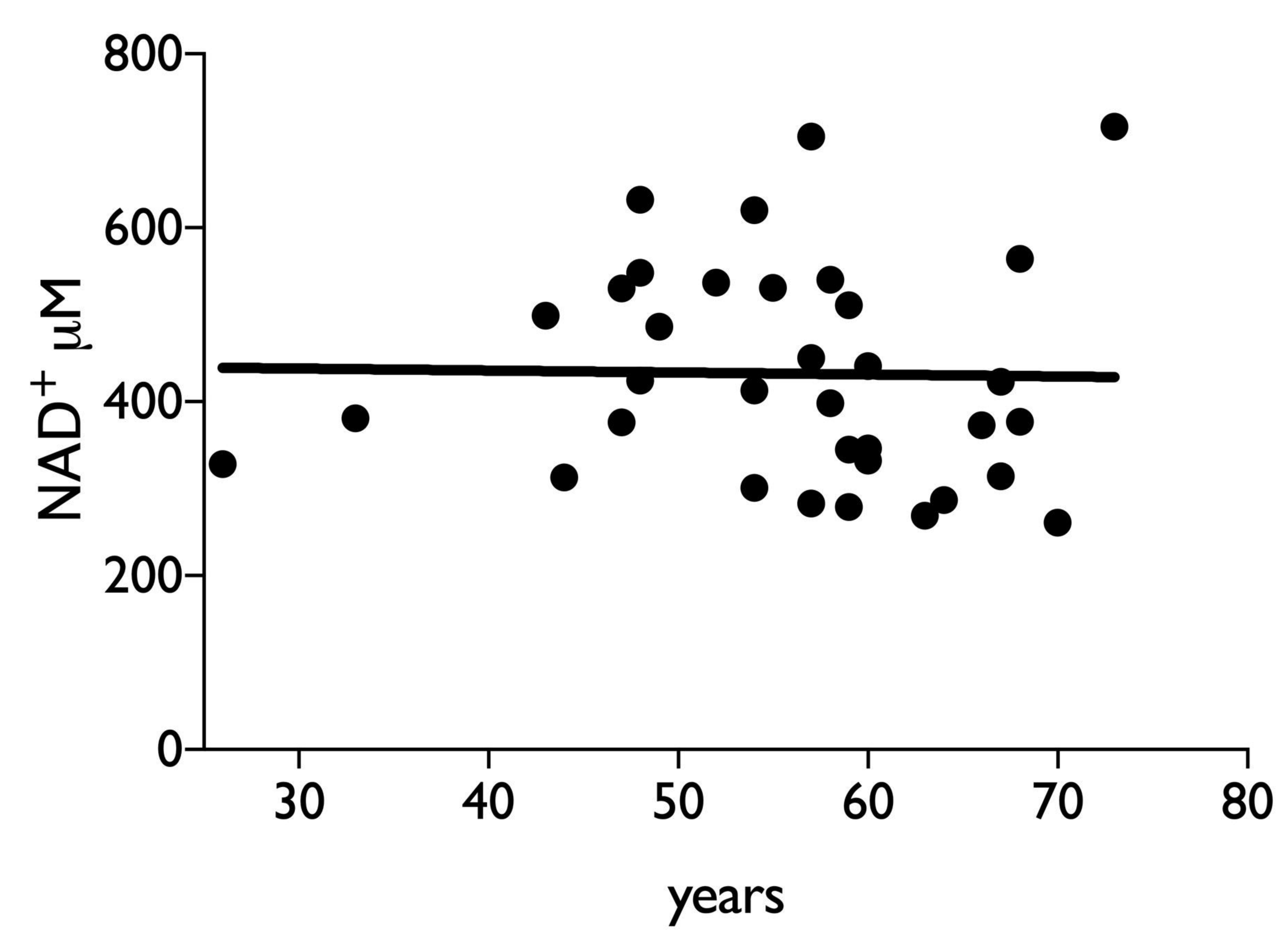

AST

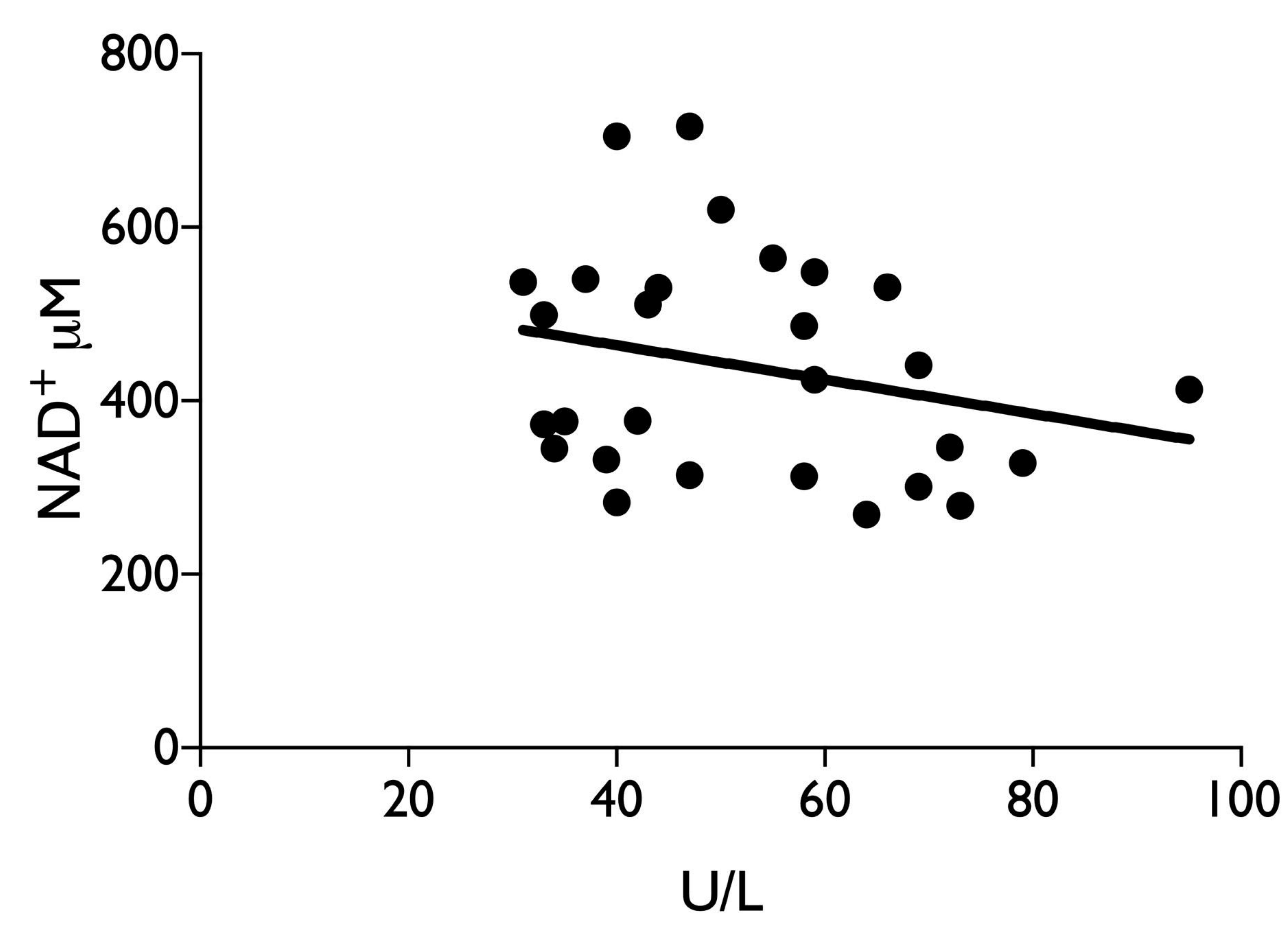

BMI

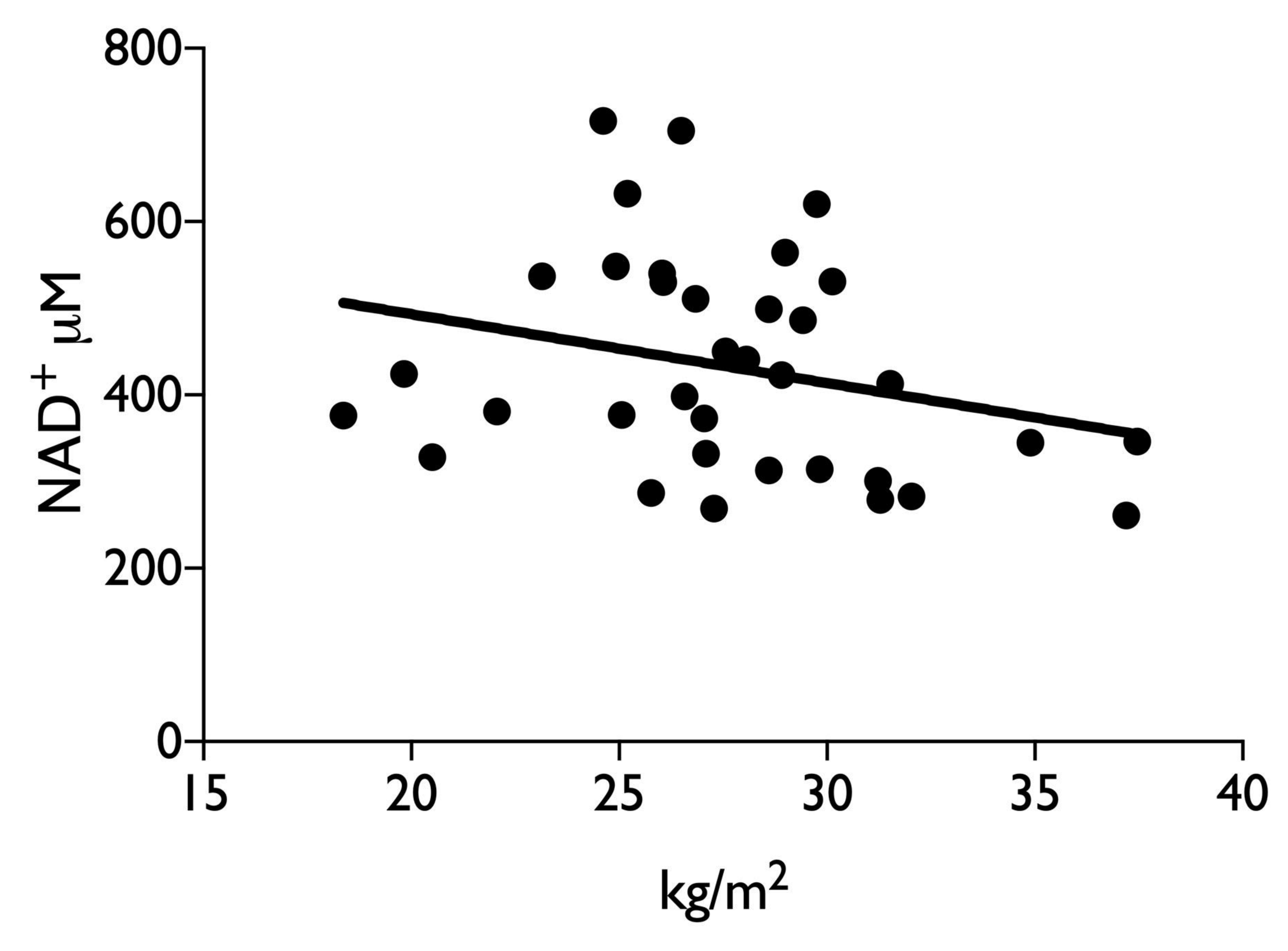


Glutathione

$\mathbf{A}$

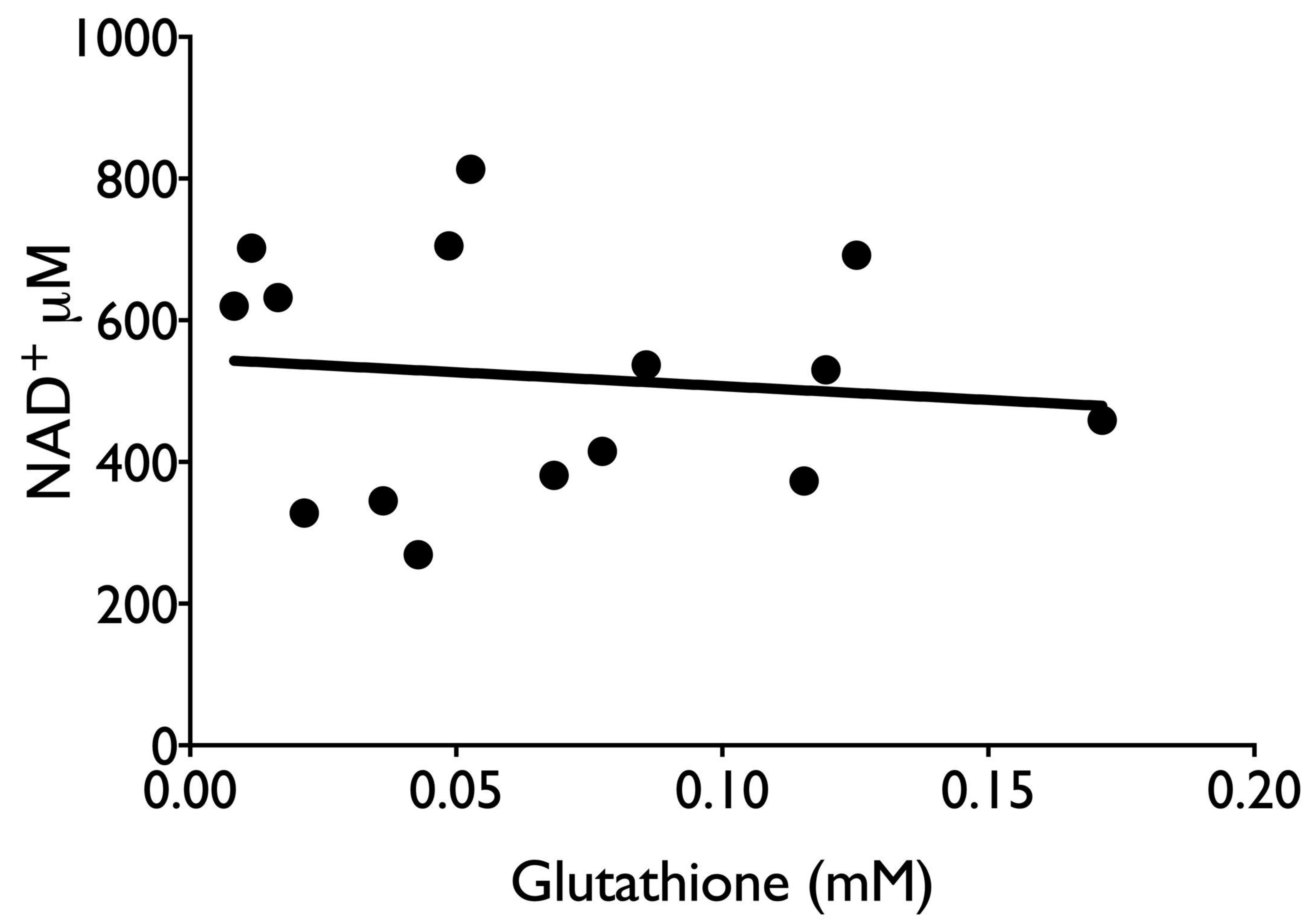

Cuperoxidase dismutase activity

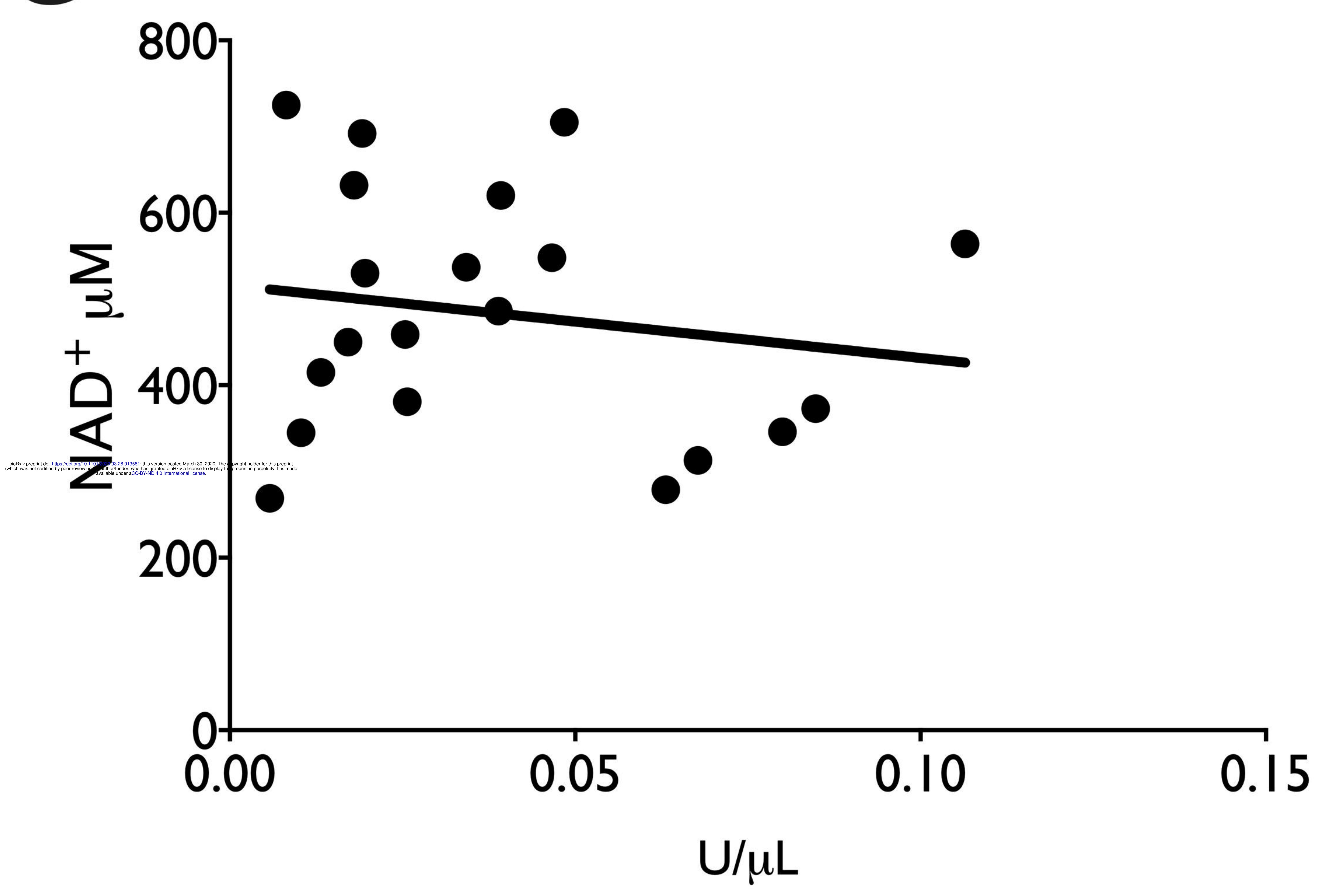

B

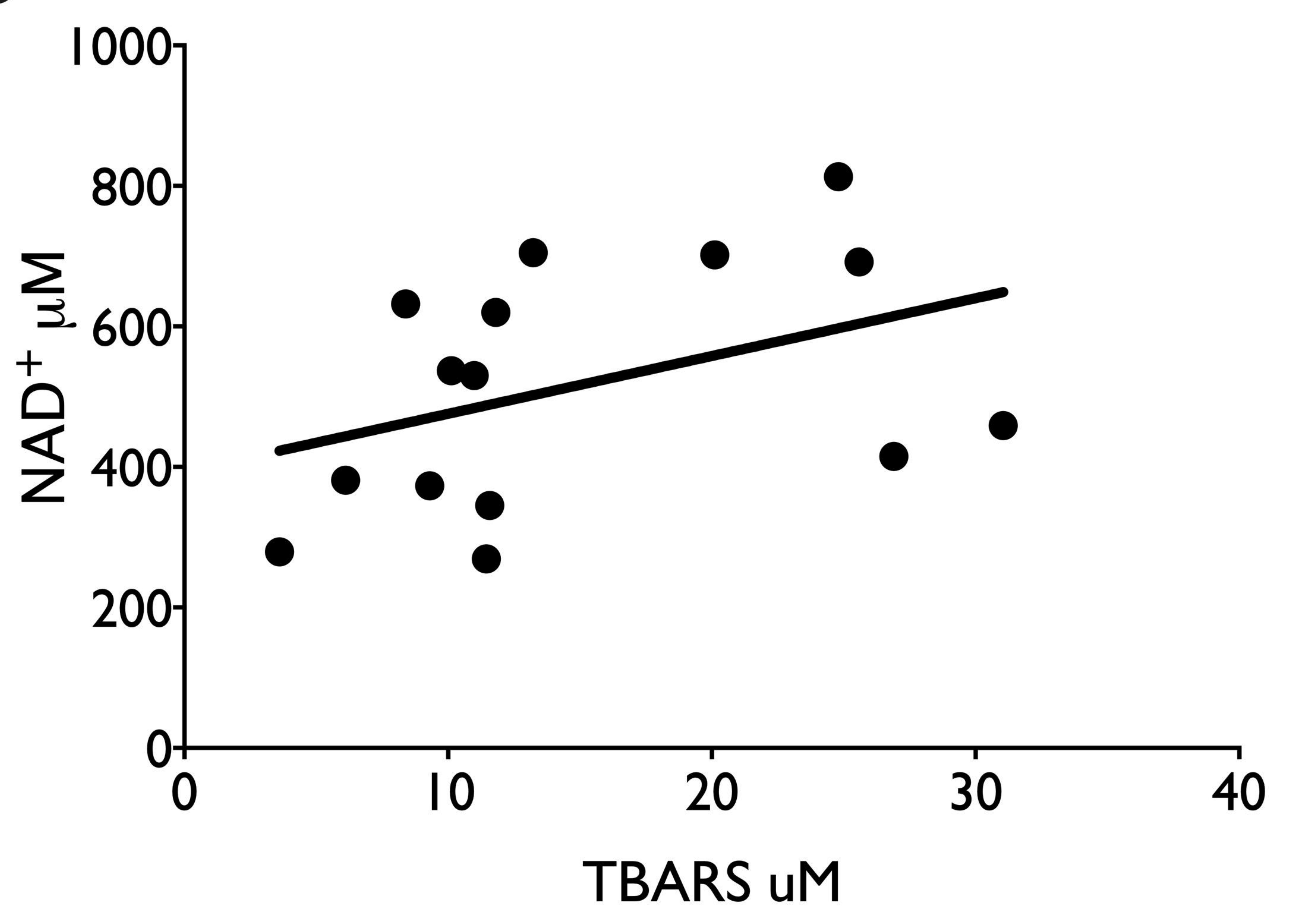

Myeloperoxidase activity

D

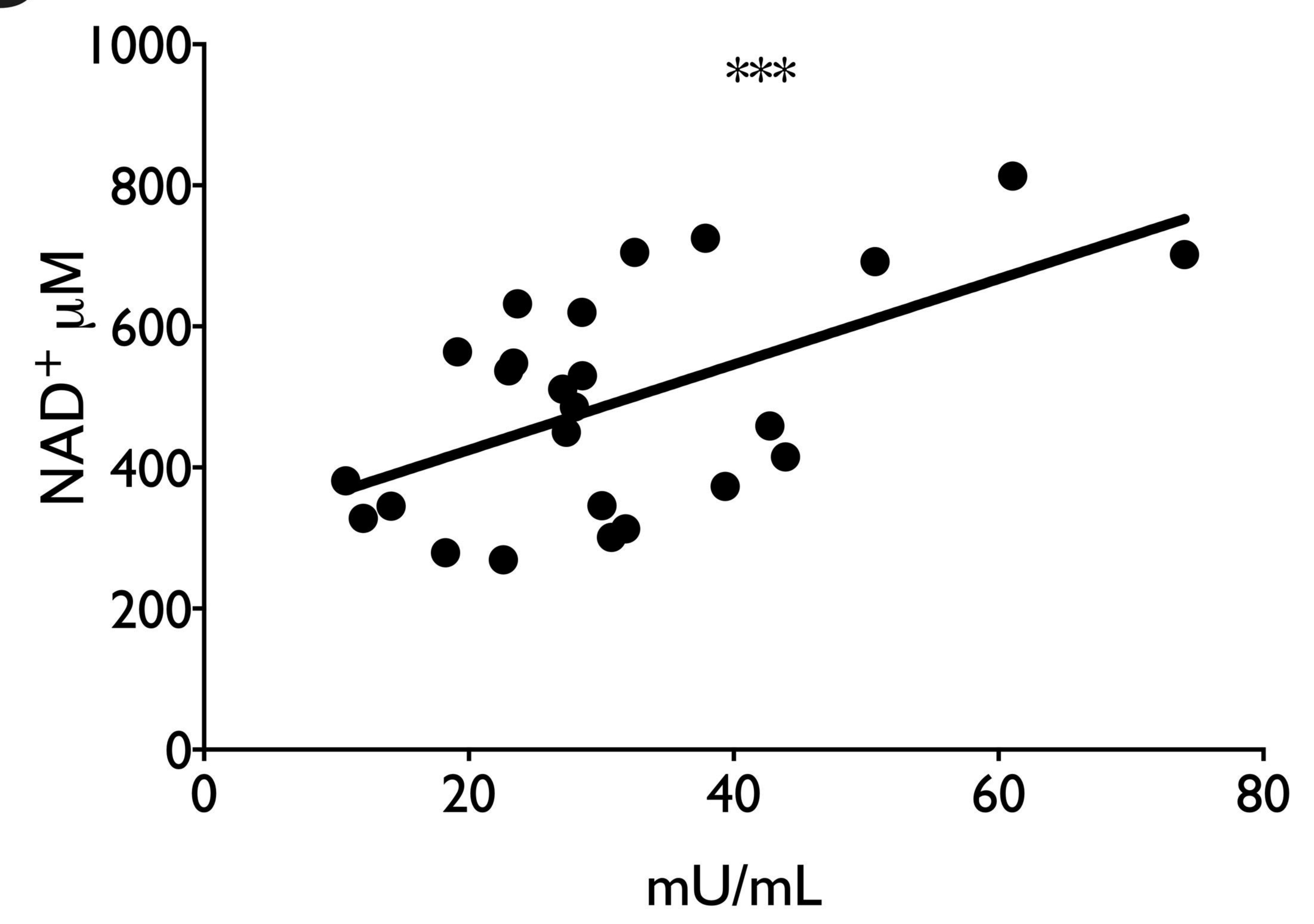

